\title{
POR QUE SOMOS CONTRA O EMPREENDIMENTO MINERÁRIO DENOMINADO “PROJETO SERRO”? \\ UMA REFLEXÃO CRÍTICA SOBRE DEMOCRACIA E DESENVOLVIMENTO \\ INCLUSIVO NA CIDADE DO SERRO ${ }^{1}$
}

\section{WHY ARE WE AGAINST THE MINING PROJECT CALLED "PROJETO SERRO"? A CRITICAL REFLECTION ON DEMOCRACY AND INCLUSIVE DEVELOPMENT IN THE CITY OF SERRO}

Matheus de Mendonça Gonçalves Leite ${ }^{2}$

\section{RESUMO}

Este artigo tem o objetivo de expor a ampla mobilização e participação popular, inclusive das classes e grupos étnicos historicamente subalternizados na cidade do Serro/MG, nas discussões e na deliberação sobre a desconformidade socioambiental do empreendimento minerário denominado "Projeto Serro". Expõe-se, também, as razões adotadas pelo Conselho de Desenvolvimento do Meio Ambiente do Município do Serro (CODEMA) para justificar a tal declaração. Pretende-se, assim, responder as críticas formuladas contra a decisão do CODEMA, demonstrando que tais críticas são meras hipóteses mentais dissociadas da realidade do processo social de discussão e deliberação. As críticas não têm, também, qualquer relação com os dados concretos do empreendimento minerário. Pretende-se, então, reconstruir os dados concretos do empreendimento minerário e do processo de discussão e deliberação. E, a partir de dados concretos, formular as categorias expressivas do empreendimento minerário e do processo de discussão e deliberação, comparando-as com as críticas formuladas contra a decisão do CODEMA. Concluir-se-á, então, que as críticas são equivocadas e não expressam a realidade do que foi o processo de discussão e deliberação sobre a desconformidade socioambiental, que, além de contar com ampla participação popular, assegurou a prevalência dos interesses da população serrana, em detrimento da acumulação do capital.

\footnotetext{
${ }^{1}$ Este artigo científico é o resultado das pesquisas realizadas no âmbito do Projeto de Extensão "A luta pelo reconhecimento dos direitos fundamentais das comunidades remanescentes de quilombo", para a defesa jurídica dos direitos étnicos e territoriais das comunidades quilombolas existentes no Estado de Minas Gerais. O projeto de extensão é financiado pela Pró-Reitoria de Extensão da Pontifícia Universidade Católica de Minas Gerais (PROEX/PUC-Minas) desde o ano de 2009 e atuou, dentre outros conflitos, na defesa dos interesses da comunidade quilombola de Queimadas contra a implantação do empreendimento minerário denominado "Projeto Serro".

2 Doutor em Teoria do Direito (2014) e Mestre em Direito Público (2008) pela Pontifícia Universidade Católica de Minas Gerais. Graduado em Direito pela Faculdade de Direito Milton Campos. Atualmente é Professor Adjunto IV da Pontifícia Universidade Católica de Minas Gerais, lecionando as seguintes disciplinas: Introdução ao Estudo do Direito, Filosofia do Direito, Hermenêutica e Argumentação Jurídica e Direito Previdenciário. Pontifícia Universidade Católica de Minas Gerais (PUC-Minas) - Brasil. ORCID: https://orcid.org/0000-0002-8668-4727 E-mail: matheusleite@pucminas.br
} 
Palavras-chave: Democracia e Justiça Socioambiental; Classe, Etnia e Meio Ambiente; Empreendimentos Minerários; Comunidades Quilombolas e Territórios; Preservação dos Recursos Hídricos.

\begin{abstract}
This article aims to expose the wide mobilization and popular participation, including the classes and ethnic groups historically subalternized in the city of Serro/MG, in the discussions and deliberation about the socioenvironmental disconformity of the mining project denominated "Projeto Serro". It is expose the reasons accepts by the Council for the Development of the Environment of the Municipality of Serro (C.O.D.E.M.A) to justify the declaration of socio-environmental discomfort of the mining project. The aim is to respond to the criticisms against C.O.D.E.M.A's decision, demonstrating that these criticisms are mere mental hypotheses dissociated from the reality of the social process of discussion and deliberation about the socio-environmental disconformity of the mining project. The criticisms also do not have any relation with the concrete data of the mining project denominated "Projeto Serro". It is intended, then, to reconstruct the concrete data of the mining enterprise and the process of discussion and deliberation about the socio-environmental disconformity of the mining enterprise. And from these concrete data, formulate the expressive categories of the mining enterprise and the process of discussion and deliberation, comparing them with the criticisms. It will be concluded, then, the criticisms are false and do not express the reality of what was the process of discussion and deliberation about the socio-environmental disconformity of the mining project denominated "Projeto Serro", which, besides counting on broad popular participation, ensured the prevalence of the interests of all classes and ethnic groups constituent of mountain society, to the detriment of the accumulation of capital.
\end{abstract}

Keywords: Democracy and Social and Environmental Justice; Class, Ethnicity and Environment; Mining enterprises; Maroons Communities and Territories; Preservation of Water Resources.

\title{
1. INTRODUÇÃO
}

No ano de 2015, o Projeto de Extensão "A luta pelo reconhecimento dos direitos fundamentais das comunidades remanescentes de quilombo" prestou assistência jurídica à comunidade quilombola de Queimadas, na defesa de seus direitos étnicos e territoriais, contra a implantação, no interior de seu território, do empreendimento minerário denominado "Projeto Serro"3.

\footnotetext{
${ }^{3}$ O Estudo de Impacto Ambiental/Relatório de Impacto Ambiental define o escopo do empreendimento minerário nos seguintes termos: "O Projeto denominado "Projeto Serro" refere-se à lavra de minério de ferro em escala de produção de 500.000 t/ano, e posterior beneficiamento a seco, em área contida dentro da poligonal do Decreto de Lavra 1.734/1963, Processo DNPM 5130/1956, no município do Serro/MG. Neste local já se encontra instalada vol.13,nº.02, RiodeJaneiro,2020.pp. 1023-1068 1024
} 
A atuação extensionista teve início com a formação de um grupo de estudos, de caráter transdisciplinar, com a finalidade de analisar o Estudo de Impacto Ambiental/Relatório de Impacto Ambiental (EIA/RIMA) do empreendimento minerário. O EIA/RIMA foi elaborado pela empresa Arcadis Logos S.A, com a finalidade de cumprir as exigências legais para a obtenção do licenciamento ambiental do empreendimento minerário a ser implantado no município do Serro, Estado de Minas Gerais.

O EIA/RIMA apresenta as principais características do empreendimento minerário, com a indicação das condições sociais e ambientais da área aonde se pretende implantar o empreendimento, prevendo, ainda, os impactos socioambientais esperados (positivos e negativos), bem como propõe as ações e programas necessários para assegurar a preservação da qualidade ambiental, social e cultural na área/sociedade de implantação do empreendimento minerário.

O grupo de estudos pretendia construir, dialogicamente, com as lideranças quilombolas, uma compreensão dos impactos da implantação do empreendimento minerário em relação à forma de vida quilombola, bem como dos direitos étnicos e territoriais que poderiam ser invocados para a proteção da forma de vida quilombola.

O grupo de estudos do EIA/RIMA foi composto por professores e alunos que atuavam nos Projetos de Extensão "A luta pelo reconhecimento dos direitos fundamentais das comunidades remanescentes de quilombos" e "Lições da Terra: projeto interdisciplinar de direito étnicos", viabilizando-se, assim, uma análise transdisciplinar do empreendimento minerário a partir dos saberes científicos das áreas de Ciências Sociais, Ciências Biológicas e Ciências Jurídicas ${ }^{4}$.

O grupo de estudos constatou que o empreendimento minerário iria se afetar diretamente o território da comunidade quilombola de Queimadas, impactando, de modo negativo, a continuidade do seu modo de ser e viver. Pois, o território quilombola é a base material que proporciona a união do grupo e a reprodução material e simbólica do modo peculiar de vida da comunidade étnica. A implantação do empreendimento minerário iria inviabilizar a continuidade da comunidade quilombola no seu território tradicional em virtude da degradação

\footnotetext{
uma Planta Azteca, a qual será adequadamente repotenciada ou complementada para atender à demanda de produção do Projeto Serro" (EIA/RIMA, vol. I, 2014, p. 13).

${ }^{4} \mathrm{O}$ grupo de estudos era formado pelos professores Ricardo Ferreira Ribeiro (PUC-Minas, ciências sociais), Juliana de Lima Passos Rezende (PUC-Minas, ciências biológicas) e Matheus de Mendonça Gonçalves Leite (PUC-Minas, Direito). Participavam, na condição de discentes extensionistas, os seguintes alunos: Ana Beatriz Campos Nunes (Direito), Mariana Gomes Miranda (Direito), Micaella Kiane de Oliveira Mendes (Ciências Sociais), Bruna Maria Maia (Direito), Karla Silva Oliveira (Direito), Larissa Rabelo Nunes (Direito) e Mateus Lima de Pinho (Direito).
} 
dos recursos naturais neles existentes, cuja preservação é imprescindível para a reprodução material e simbólica do modo de vida quilombola.

Constatou-se, ainda, que a implantação do empreendimento minerário iria ocorrer em área de entorno da área central da cidade do Serro, cujo conjunto foi tombado em 8 de abril de 1938, por meio do processo n ${ }^{\circ} 65-\mathrm{T}-38$, inscrição n ${ }^{\circ} 25$, constando do Livro de Belas-Artes, v. 1, p. 6, pelo Instituto do Patrimônio Histórico e Artístico Nacional (IPHAN). Ora, na área do entorno do bem tombado, fica proibida a construção de edificações que possam impactar negativamente a ambiência do bem tombado, nos termos do disposto no artigo 18 do DecretoLei n. ${ }^{\circ} 25 / 37^{5}$.

Constatou-se, também, que a implantação do empreendimento minerário iria produzir impactos negativos no Rio do Peixe e no Córrego do Siqueira, em virtude da inevitável diminuição da disponibilidade hídrica ocasionada pela extinção de nascentes existentes no local. Além de compor a paisagem da região, esses cursos d'água são utilizados para o abastecimento humano, dessedentação de animais, lazer e outros usos sociais.

Por fim, constatou-se que o empreendimento minerário iria se sobrepor à zona de amortecimento do Parque Estadual do Pico do Itambé (PEPI), causando impactos negativos sobre os recursos naturais existentes no interior da unidade de preservação integral.

O projeto de extensão defendeu, então, a declaração de desconformidade socioambiental do empreendimento minerário denominado "Projeto Serro". E, na audiência pública realizada no dia 28 de outubro de 2015, o Conselho de Desenvolvimento do Meio Ambiente do Município do Serro (CODEMA) recomendou ao Prefeito do Serro que declarasse a desconformidade, nos seguintes termos:

Art. $1^{\circ}$ - Com base no art. 225 - CAPUT da Constituição Federal que prevê o Princípio de Prevenção, que incumbe ao Poder Público e a coletividade o dever de proteger e preservar o meio ambiente às futuras gerações.

Art. $2^{\circ}$ - Com base nos artigos 39, parágrafo $2^{\circ}$, art. 41 e art. 47, inciso II, da Lei Complementar 075/2007, que institui o Plano Diretor do Município de Serro, fica declarada a não conformidade do empreendimento Projeto Serro - Planta Asteca da Empresa Anglo American com a legislação de Uso e Ocupação do solo do Município.

Art. $3^{\circ}$. Com base nos artigos $6^{\circ}, 7^{\circ}$ e 15 da Convenção 169 da Organização Internacional do Trabalho, fica declarada a não Conformidade Ambiental até que

\footnotetext{
5 “Art. 18. Sem prévia autorização do Serviço do Patrimônio Histórico e Artístico Nacional, não se poderá, na vizinhança da coisa tombada, fazer construção que lhe impeça ou reduza a visibílidade, nem nela colocar anúncios ou cartazes, sob pena de ser mandada destruir a obra ou retirar o objéto, impondo-se nêste caso a multa de cincoenta por cento do valor do mesmo objeto"/
} 
seja realizada consulta livre, prévia e informada à Comunidade Quilombola de Queimadas, que está situada na área de influência direta do empreendimento minerário, com obtenção de consentimento da Comunidade. (Deliberação n. ${ }^{\circ}$ 001, de 28 de outubro de 2015, do Conselho de Desenvolvimento do Meio Ambiente do Município do Serro).

E, acatando a recomendação do CODEMA, o Prefeito Municipal do Serro homologou em "todos os termos e fundamentos a deliberação 01 , de 28 de outubro de 2015, do Conselho Municipal do Desenvolvimento do Meio Ambiente - CODEMA, para fins de declarar a não conformidade do Projeto Serro - Planta Azteca da Empresa Anglo American”, em decisão proferida no dia 20 de novembro de 2015.

Após aproximadamente dois anos da decisão administrativa, que declarou a desconformidade socioambiental do empreendimento minerário denominado "Projeto Serro", a discussão sobre a validade e legitimidade da decisão administrativa ressurgiu por iniciativa de pessoas insatisfeitas com a proibição da implantação do empreendimento minerário.

Formulou-se, então, 2 críticas principais à decisão administrativa que declarou a desconformidade socioambiental do "Projeto Serro".

A primeira crítica, que pode ser denominada de crítica procedimental, consubstancia-se na afirmação de que a decisão administrativa foi tomada sem se permitir que a população pudesse opinar sobre os rumos sociais e econômicos da cidade. Afirmou-se que a decisão administrativa deveria ter sido "precedida de ampla campanha de esclarecimento da população sobre benefícios e malefícios da atividade, [...] com envolvimento das universidades e dos órgãos públicos (Iphan, IEF, secretaria de meio ambiente etc.)". Os críticos afirmam, então, que a decisão administrativa demonstraria o "despreparo dos gestores no trato democrático" da questão da implantação do empreendimento minerário.

A segunda crítica, que pode ser denominada de crítica de conteúdo, sustenta que a decisão administrativa desconsiderou as consequências benéficas que poderiam ser proporcionadas pela implantação do empreendimento minerário, tais como "o aumento da arrecadação de impostos municipais", "o aquecimento do comércio de produtos e serviços locais", "o aumento da oferta de empregos", "a redução da informalidade trabalhista", "a valorização dos imóveis urbanos e rurais", "uma melhor distribuição de renda" e "o aumento de oportunidades econômicos-financeiro-cultural-social”.

As críticas acima indicadas são meras cogitações mentais dissociadas tanto da realidade do processo social de discussão e deliberação sobre a desconformidade socioambiental do "Projeto Serro", quanto com o que é, de fato, o empreendimento minerário denominado 
"Projeto Serro", especialmente sobre as externalidades que seriam tendencialmente produzidas pela implantação do empreendimento minerário.

É importante observar, de antemão, que a promoção de uma discussão científica sobre o empreendimento minerário denominado "Projeto Serro", bem como sobre o processo administrativo que declarou a desconformidade socioambiental do empreendimento minerário, não pode se basear em crenças subjetivas e dissociadas do processo da vida real. Ao contrário, a discussão deve estar baseada nos dados concretos do empreendimento minerário e do processo de discussão e deliberação sobre a desconformidade socioambiental.

Assim, a pesquisa científica deve começar pela análise do real e do concreto, num esforço teórico por captar os elementos constitutivos da realidade. A capacidade abstrativa do pensamento ${ }^{6}$ possibilita separar do elemento abstraído as suas determinações mais concretas (os elementos particulares), as suas determinações mais gerais (os elementos de universalidade) e as suas determinações imediatas, que mostram como o universal se apresenta no concreto (singularidade).

A construção intelectiva das determinações gerais permite a formulação de categorias ${ }^{7}$ reflexivas, que exprimem o modo de ser do objeto que se deseja conhecer, permitindo, assim, antecipar as tendências de desenvolvimento deste objeto. Ou seja, essas categorias são

\footnotetext{
${ }^{6}$ A capacidade de abstração, e sua importância na construção de teorias científicas, é explicada por José Paulo Netto (2011, p. 44), nos seguintes termos: "A abstração é a capacidade intelectiva que permite extrair de sua contextualidade determinada (de uma totalidade) um elemento, isolá-lo, examiná-lo; é um procedimento intelectual sem o qual a análise é inviável - aliás, no domínio do estudo da sociedade, o próprio Marx insistiu com força em que a abstração é um recurso indispensável para o pesquisador. A abstração, possibilitando a análise, retira do elemento abstraído as suas determinações mais concretas, até atingir 'determinações as mais simples'. Neste nível, o elemento abstraído torna-se 'abstrato' - precisamente o que não é na totalidade de que foi extraído: nela, ele se concretiza porquanto está saturado de 'muitas determinações'. A realidade é concreta exatamente por isso, por ser 'a síntese de muitas determinações', a 'unidade do diverso' que é própria de toda totalidade. O conhecimento teórico é, nesta medida, para Marx, o conhecimento do concreto, que constitui a realidade, mas que não se oferece imediatamente ao pensamento: deve ser reproduzido por este e só 'a viagem de modo inverso' permite esta reprodução. Já salientamos que, em Marx, há uma contínua preocupação em distinguir a esfera do ser da esfera do pensamento; o concreto a que chega o pensamento pelo método que Marx considera 'cientificamente exato' (o 'concreto pensado') é um produto do pensamento que realiza 'a viagem de modo inverso'. Marx não hesita em qualificar este método como aquele 'que consiste em elevar-se do abstrato ao concreto', 'único modo' pelo qual 'o cérebro pensante' 'se apropria do mundo"'.

${ }^{7} \mathrm{Na}$ tentativa de reconstruir a metodologia científica adotada por Karl Marx, com o objetivo de conhecer a sociedade burguesa ou moderna, José Paulo Netto (2011, p. 46) afirma que as categorias "exprimem [...] formas de modo de ser, determinações de existência, frequentemente aspectos isolados de [uma] sociedade determinada ou seja: elas são objetivas, reais (pertencem à ordem do ser - são categorias ontológicas); mediante procedimentos intelectivos (basicamente, mediante a abstração), o pesquisador as reproduz teoricamente (e, assim, também pertencem à ordem do pensamento - são categorias reflexivas). Por isso mesmo, tanto real quanto teoricamente, as categorias são históricas e transitórias: as categorias próprias da sociedade burguesa só têm validez plena no seu marco (um exemplo: trabalho assalariado)".
} 
historicamente determinadas, na medida em que exprimem um objeto tal como ele está determinado num momento histórico.

Uma vez armado com as categorias expressivas do real, o cientista deve retornar ao concreto, que, na viagem de volta, não é mais uma representação caótica de um todo, mas uma rica totalidade de muitas determinações e relações que constituem o objeto. Assim, à medida em que são apropriadas para explicar o movimento do real, as categorias se mostram verdadeiras para antecipar as tendências de movimentação do real.

Nesse sentido, Karl Marx (2011, p. 54/55) expõe o método científico, que fora por ele utilizado no Capital para estudar as categoriais fundamentais da sociedade burguesa/sociedade moderna, nos seguintes termos:

O concreto é concreto porque é a síntese de múltiplas determinações, portanto, unidade da diversidade. Por essa razão, o concreto aparece no pensamento como processo da síntese, como resultado, não como ponto de partida, não obstante seja o ponto de partida efetivo e, em consequência, também o ponto de partida da intuição e da representação. Na primeira via, a representação plena foi volatilizada em uma determinação abstrata; na segunda, as determinações abstratas levam à reprodução do concreto por meio do pensamento. Por isso, Hegel caiu na ilusão de conceber o real como resultado do pensamento que sintetiza-se em si, aprofunda-se em si e movimenta-se a partir de si mesmo, enquanto método de ascender do abstrato ao concreto é somente o modo do pensamento de apropriarse do concreto, de reproduzi-lo como um concreto mental. Mas de forma alguma é o processo de gênese do próprio concreto. [...]

Pretende-se, então, reconstruir os dados concretos do empreendimento minerário e do processo de discussão e deliberação sobre a sua desconformidade socioambiental. E, a partir destes dados concretos, formular as categorias expressivas do empreendimento minerário e do processo de discussão e deliberação, comparando-as com as críticas formulados por aqueles que não se conformaram com a declaração de desconformidade socioambiental do empreendimento minerário. Por fim, demonstrar-se-á o equívoco das críticas elaboradas e da ampla e democrática participação popular no procedimento administrativo instaurado no âmbito do CODEMA.

\section{RESPOSTA À CRÍTICA PROCEDIMENTAL: A DEMOCRACIA PARTICIPATIVA QUE CARACTERIZOU O PROCEDIMENTO ADMINISTRATIVO INSTAURADO NO ÂMBITO DO CODEMA.}

No dia 17 de novembro de 2014, a sociedade empresária “Anglo American Minério de Ferro Brasil S.A.” requereu, à Prefeitura Municipal do Serro, a declaração de conformidade do 
empreendimento minerário denominado "Projeto Serro" às leis de uso e ocupação do solo, nos termos do disposto no artigo 10, $\S 1^{\text {o }}$, da Resolução CONAMA n. ${ }^{\circ}$ 237/97 ${ }^{8}$.

O empreendimento minerário denominado "Projeto Serro" pretendia realizar lavra de minério de ferro, em escala de produção de 500.000 toneladas/ano, e posterior beneficiamento a seco, de acordo com o Estudo de Impacto Ambiental e Relatório de Impacto Ambiental (EIA/RIMA, Volume I, 2014, p. 13).

O Prefeito Municipal encaminhou o requerimento administrativo ao Conselho de Desenvolvimento do Meio Ambiente do Município do Serro (CODEMA), com a finalidade de propiciar, aos diferentes setores da sociedade civil, a participação no processo de tomada de decisão sobre a autorização para implantação do empreendimento minerário, nos termos do disposto no art. 2. ${ }^{\circ}$, incisos XV e XVII, da Lei Municipal n. ${ }^{\circ} 1.815$, de 27 de dezembro de $2005^{9}$.

O CODEMA é órgão público colegiado, deliberativo e normativo, vinculado à Secretaria Municipal de Turismo, Cultura, Meio Ambiente e Desenvolvimento Sustentável, formado por representantes do Poder Público e da sociedade civil, com a finalidade de propiciar ampla participação popular nos processos de tomada de decisão sobre questões socioambientais.

No ano de 2015, o CODEMA era composto por 4 representantes do Poder Público (Prefeitura Municipal, Câmara Municipal, Polícia Militar Ambiental e Instituto Estadual de Floresta - IEF) e por 4 representantes da sociedade civil (Associação Comercial do Serro,

\footnotetext{
${ }^{8}$ A competência para decidir sobre o processo de licenciamento ambiental de atividades mineradoras no município do Serro é da Superintendência Regional do Meio Ambiente do Jequitinhonha (Supram Jequitinhonha), que é um órgão colegiado vinculado à Secretaria de Estado de Meio Ambiente e Desenvolvimento Sustentável do Estado de Minas Gerais (SEMAD). Entretanto, a legislação ambiental exige que o empreendedor instrua o requerimento de licenciamento ambiental com inúmeros documentos, projetos e estudos ambientais, dentre os quais: a "certidão da Prefeitura Municipal, declarando que o local e o tipo de empreendimento ou atividade estão em conformidade com a legislação aplicável ao uso e ocupação do solo e, quando for o caso, a autorização para supressão de vegetação e a outorga para o uso da água, emitidas pelos órgãos competentes" (o artigo $10, \S 1 .^{\circ}$, da Resolução CONAMA n. ${ }^{\circ}$ 237/97). Isso significa que, para se dar início ao processo administrativo de licenciamento ambiental, o empreendedor precisa obter a concordância do Município em que se pretende instalar o empreendimento minerário. Pois, sem a declaração de conformidade com a legislação aplicável ao uso e ocupação do solo, o processo de licenciamento ambiental não pode, sequer, ser iniciado pelo empreendedor.

9 “Art. 2 ${ }^{\circ}$. A Política Municipal do Meio Ambiente tem por objetivo a preservação, melhoria e recuperação da qualidade ambiental propícia à vida em todas as suas formas de expressão visando assegurar condições ao desenvolvimento socioeconômico e a proteção à dignidade da vida humana, atendidos os seguintes princípios: [...] IX - participação popular, por intermédio do CODEMA ou audiências públicas, na definição dos planos, programas, projetos, normas, padrões e critérios ambientais para o município, assim como na tomada de decisões que potencialmente afetem a qualidade do ambiente e da vida da população local” (grifos nossos).
} 
Sindicato dos Trabalhadores Rurais do Serro, Pontifícia Universidade Católica de Minas Gerais e Representante da Sociedade Civil de Notório Saber) ${ }^{10}$.

O CODEMA foi criado pela Lei Municipal n. ${ }^{\circ} 1.816 / 2005^{11}$ e integra o Sistema Nacional do Meio Ambiente (SISNAMA), com a finalidade específica de propiciar a mais ampla participação popular na tomada de decisões sobre empreendimentos potencialmente poluidores. A função do CODEMA é assimilar as mais diferentes opiniões e informações, interesses e valores, provenientes dos grupos e classes sociais constitutivas da sociedade serrana, na tentativa de se construir uma decisão administrativa consensual sobre a implantação de empreendimentos potencialmente poluidores.

Em outras palavras, a criação do CODEMA expressa a tentativa de democratização da Administração Pública no município do Serro, por meio da institucionalização de procedimentos discursivos destinados a assegurar a igual participação de todos os possíveis afetados na tomada de decisão sobre a autorização de implantação de empreendimentos econômicos potencialmente poluidores. Os procedimentos discursivos possuem, assim, a finalidade de construir um consenso social sobre as decisões coletivamente obrigatórias, que afetarão a vida de todos aqueles que se submetem ao Direito e se legitimam na medida em que são aceitas por aqueles que deverão se submeter à decisão administrativa.

Nesse sentido, Marçal Justen Filho apresenta os fundamentos de uma Administração Pública democrática, que, ao invés de impor certas decisões administrativas aos diversos grupos e classes sociais por meio da tomada de decisão solipsista de agentes públicos, busca construir consensualmente a decisão administrativa que atenda, na maior medida do possível, os legítimos interesses dos grupos e classes sociais constitutivas da sociedade civil. O autor (2009, p. 12/13) afirma que:

O tema da legitimação se relaciona com o modo de comunicação entre o governo e a sociedade. Se o direito não encontra seu fundamento de validade numa base religiosa ou puramente moral, e como não pode manter-se por via da força, então a única alternativa restante é o consenso dos cidadãos. Esse consenso, na democracia, é obtido por meio do respeito a procedimentos.

\footnotetext{
${ }^{10}$ A Lei Municipal n. ${ }^{\circ} 3.074$, de 25 de maio de 2017, alterou a composição do CODEMA, que, a partir da data da publicação da referida lei, passa a ser composto por 8 representantes do Poder Público e 8 representantes da sociedade civil.

${ }^{11} \mathrm{O}$ artigo $1^{\circ}$ da Lei Municipal n. $.^{\circ} 1.816 / 2005$ dispõe que: “Art. $1^{\circ}$ - Fica criado, no âmbito da Secretaria Municipal de Turismo, Cultura, Meio Ambiente e Desenvolvimento Sustentável, o Conselho de Desenvolvimento do Meio Ambiente - CODEMA. Parágrafo Único - O CODEMA é um órgão colegiado, de liberativo e normativo de assessoramento ao Poder Executivo Municipal no âmbito de sua competência sobre as questões ambientais propostas nesta e demais leis correlatas do Município".
} 
Mas esse consenso pressupõe, primeiro, a possibilidade de cada indivíduo ser tratado como igual, como titular de direitos insuprimíveis. Não há consenso entre indivíduos que se qualificam como desiguais. Portanto, é indispensável o reconhecimento dos direitos fundamentais para haver o consenso.

Depois, o reconhecimento da igualdade de todos os cidadãos conduz ao direito de participação igualitário. Essa participação se faz por meio de um processo de comunicação. Mais precisamente, as decisões adotadas por um governo e o direito produzido são reflexos desse processo comunicacional.

HABERMAS assinala que, "porque a questão da legitimidade das leis garantidoras da liberdade tem de encontrar uma resposta dentro do direito positivo, o contrato social não pode impor e fazer valer o 'princípio do direito' senão ligando a formação da vontade política do legislador a condições de um procedimento democrático, sob as quais os resultados produzidos conforme o procedimento expressem per se a vontade concordante ou o consenso racional de todos os implicados. Por isso, o procedimento democrático exige a adoção da mais ampla gama de possíveis alternativas para propiciar a manifestação de todos os interessados. O fundamental é que cada decisão seja produzida a partir de um procedimento que pressuponha a igualdade de todos os interessados e lhes reconheça a faculdade de participação como sujeitos dotados de direitos insuprimíveis e inalienáveis.

Esse procedimento democrático envolve a ideia de que "válidas são aquelas normas (e apenas aquelas normas) a que todos os que possam ser por ela afetados puderem prestar seu assentimento como participantes de discursos racionais".

$[\ldots]$

A legitimidade e a validade dos atos estatais não dependem da participação efetiva e real de cada cidadão. Mas somente haverá a legitimidade e a validade quando a disciplina jurídica não excluir essa participação. A validade dos atos estatais pressupõe um sistema jurídico que propicie a participação do cidadão na formação da vontade do Estado. O cidadão não é um súdito, um inferior, um servo do Estado. Os governantes e os governados encontram-se em posição de igualdade, ainda que haja competência dos primeiros de tomarem decisões vinculantes para todos. A competência decisória atribuída aos agentes estatais não se funda na posição de supremacia deles em face dos governados.

No cumprimento de sua função institucional, o CODEMA promoveu uma ampla discussão social sobre o empreendimento minerário, com a participação de diversos setores da sociedade civil, na tentativa de construir um consenso sobre a melhor decisão a ser tomada em relação ao requerimento de implantação do empreendimento minerário no Serro/MG.

A rememoração do procedimento discursivo, em todas as suas etapas e atividades realizadas, fornecerá o substrato material para o julgamento verdade/falsidade da crítica procedimental formulada por aqueles que foram contrariados pela decisão do CODEMA.

No dia 17 de abril de 2015, o CODEMA recebeu o Estado de Impacto Ambiental/Relatório de Impacto Ambiental (EIA/RIMA) do "Projeto Serro". O CODEMA realizava reuniões públicas, cuja participação era aberta a qualquer interessado, nas terceiras 
quartas-feiras de cada mês. E, no ano de 2015, as reuniões se concentravam, principalmente, nas discussões sobre o empreendimento minerário denominado "Projeto Serro".

Em virtude da complexidade do EIA/RIMA, foi firmada uma parceria com a Pontifícia Universidade Católica de Minas Gerais (PUC-Minas), por meio da qual a universidade disponibilizou professores do curso de ciências biológicas, ciências sociais e ciências jurídicas, para auxiliar na análise crítica das características do empreendimento minerário.

Assim, no dia 22 de julho de 2015, os professores Ricardo Ferreira Ribeiro (ciências sociais) e Juliana de Lima Passos Rezende (ciências biológicas) fizeram uma apresentação do EIA/RIMA para os membros do CODEMA e demais interessados, esclarecendo, principalmente, a localização e os impactos socioambientais que, provavelmente, seriam ocasionados pelo empreendimento minerário.

No dia 22 de agosto de 2015, o CODEMA, em parceria com a PUC-Minas, promoveu o Ciclo de Estudos sobre os Impactos Socioambientais do Empreendimento Minerário no Município do Serro, na Escola Municipal Irmã Carvalho. O evento teve a finalidade de envolver toda a comunidade serrana na discussão sobre a compatibilidade do empreendimento minerário com a ordenação de uso e ocupação do solo, que regula a instalação e desenvolvimento das atividades humanas ao longo do território do município

A divulgação do evento foi realizada por meio das redes sociais e das rádios locais. O município do Serro disponibilizou, ainda, transporte gratuito para viabilizar a participação das pessoas que vivem na zona rural do município, de modo a proporcionar a mais ampla participação popular nas discussões sobre o empreendimento minerário.

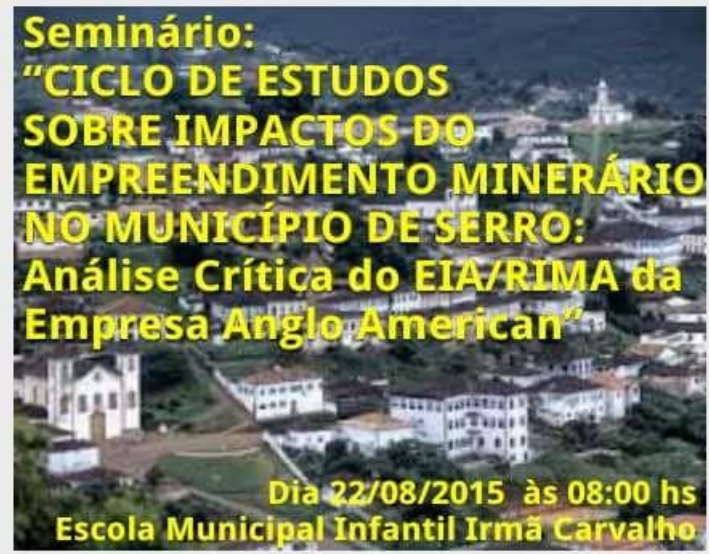

Cartaz de Divulgação do Evento Fonte: CODEMA, 2015.

A empresa mineradora foi convidada para participar do evento e, inicialmente, confirmou a participação, comprometendo-se a enviar seus técnicos para apresentação do empreendimento minerário e para o esclarecimento das dúvidas da população. Contudo, no dia anterior ao evento, a empresa mineradora informou ao CODEMA que não mais 
participaria da discussão sobre o empreendimento minerário, sem apresentar qualquer justificativa para o não comparecimento ao evento.

Ao invés de enviar seus técnicos para o esclarecimento da população do Serro sobre as características do empreendimento minerário, a empresa mineradora enviou policiais militares reformados, que, na época, eram seus empregados, para, de modo ostensivo, fotografar todas as pessoas que se manifestassem contra a mineração. A postura da empresa mineradora expressava a violência simbólica, promovida por grandes conglomerados econômicos, na tentativa de constranger as pessoas comuns a não manifestarem suas opiniões sobre a implantação do empreendimento minerário.

Ressalte-se, também, que, apesar de amplamente divulgado pelas redes sociais e pelas rádios locais, a participação da população serrana foi, parcialmente, prejudicada por boatos maliciosos que, na véspera do evento, difundiram a informação falsa de que o evento havia sido cancelado. Assim, vários moradores da zona rural deixaram de comparecer ao evento, por terem sido informados de que o CODEMA o havia cancelado.

Nesse contexto, a tentativa de desarticulação da ação política da comunidade local, bem como de grupos étnicos diferenciados, foi uma constante no processo administrativo de declaração que culminou na declaração de desconformidade socioambiental do empreendimento minerário. Em todo instante, a empresa mineradora propagava informações falsas sobre o procedimento administrativo instaurado no âmbito do CODEMA, os direitos dos povos e comunidades tradicionais e os impactos ocasionados pelo empreendimento aos recursos hídricos existentes na região.

Apesar de todas as dificuldades enfrentadas pela postura colonialista da empresa mineradora, o CODEMA proporcionou, de modo efetivo, uma ampla discussão social, aberta a todos os grupos étnicos e classes sociais constituidores da sociedade serrana, sobre os impactos positivos e negativos decorrentes da implantação do empreendimento minerário.

O Ciclo de Estudos sobre os Impactos Socioambientais do Empreendimento Minerário no Município do Serro foi o momento de maior participação da população serrana nas discussões sobre o empreendimento minerário. Naquele evento, houve, de fato, uma efetiva participação de diversos setores da sociedade civil serrana, que puderam compreender o empreendimento minerário proposto e manifestar seus interesses e reivindicações em relação à adaptação do empreendimento minerário. 


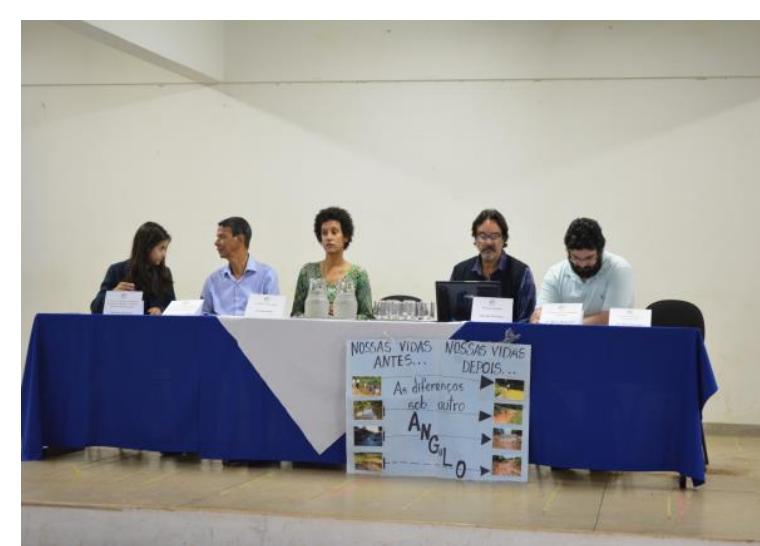

Figura 1: Mesa de Abertura do Ciclo de Estudos sobre os Impactos Socioambientais do Empreendimento Minerário no Município do Serro.

Participantes (da esquerda para direita): Maria Clara Costa Pinheiro de Azevedo (Promotora de Justiça da Comarca do Serro); Walneide Despachante (Presidente da Câmara de Vereadores do Município do Serro); Silvia Jussara Duarte (Gerente do Parque Estadual Pico do Itambé); Paulo Sérgio Torres Procópio (Presidente do CODEMA); Matheus de Mendonça Gonçalves Leite (Representante da PUC-Minas no CODEMA).

Fonte: Projeto de Extensão "A luta pelo reconhecimento dos direitos fundamentais das comunidades remanescentes de quilombo", 2015 .

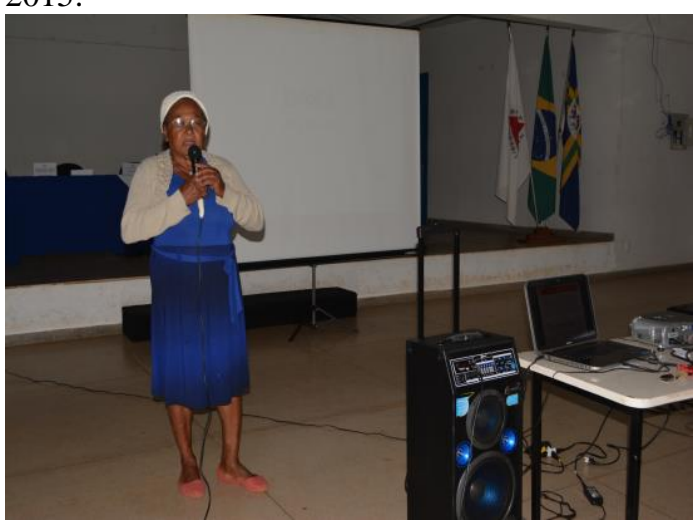

Figura 3: Discurso de liderança da comunidade quilombola de Queimadas.

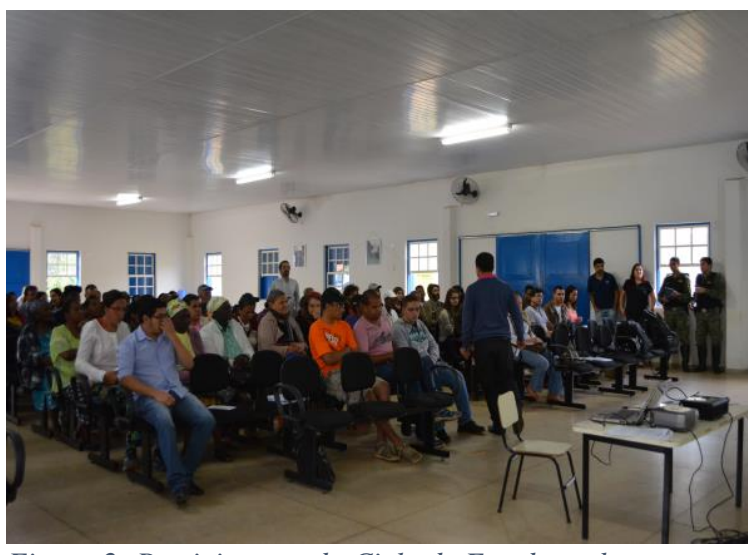

Figura 2: Participantes do Ciclo de Estudos sobre os Impactos Socioambientais do Empreendimento Minerário no Município do Serro.

Fonte: Projeto de Extensão "A luta pelo reconhecimento dos direitos fundamentais das comunidades remanescentes de quilombo", 2015.

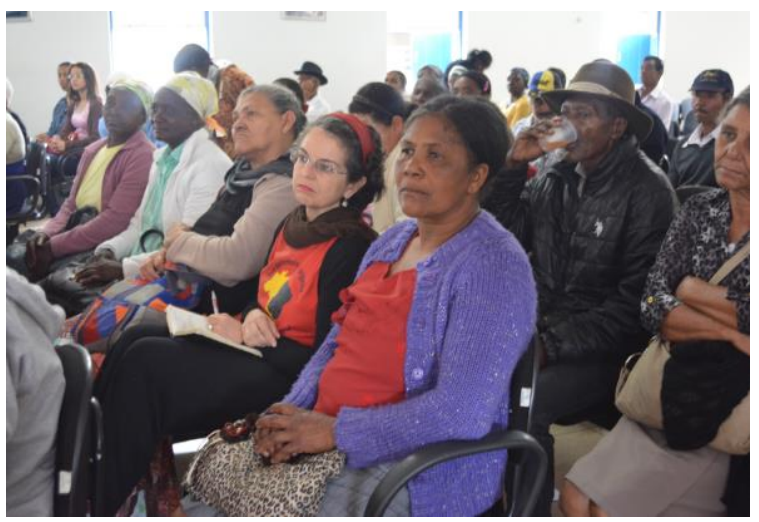

Figura 4: Lideranças quilombola no Ciclo de Estudos sobre os Impactos Socioambientais do Empreendimento Minerário no Município do Serro.

Participantes (da direita para a esquerda): Vera (Comunidade Quilombola do Baú); Flávia Assis Alves (Pesquisadora NESTH/UFMG); Clemência (Comunidade Quilombola do Ausente) e Maria Flor (Comunidade Quilombola do Ausente). 


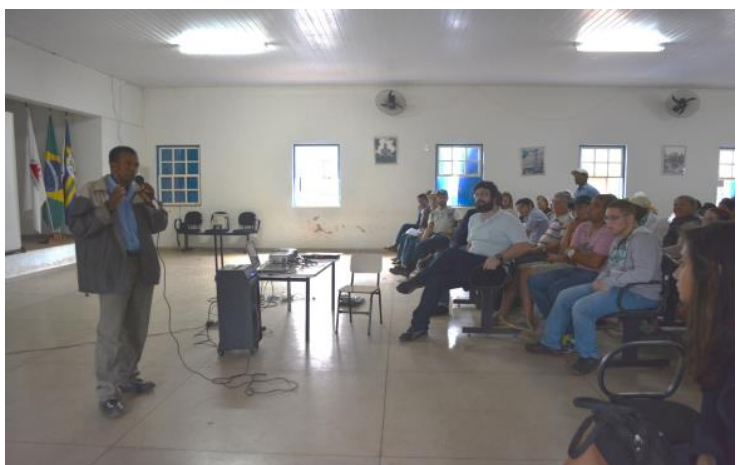

Foto 5: Discurso de André de Fátima (liderança da comunidade quilombola do Ausente)

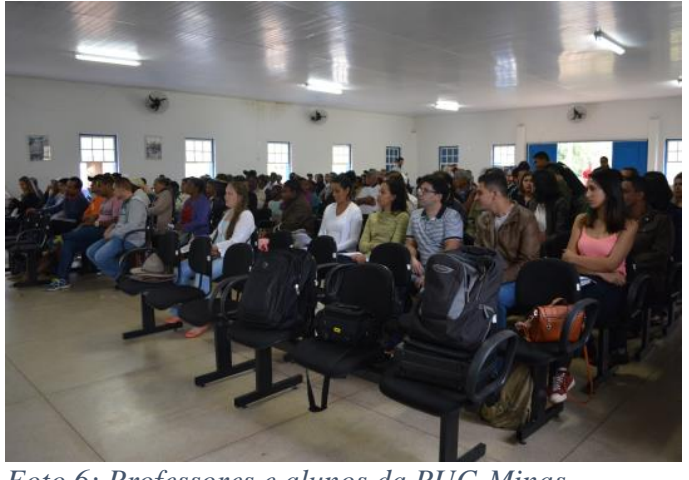

Foto 6: Professores e alunos da PUC-Minas

Fonte: Projeto de Extensão "A luta pelo reconhecimento dos direitos fundamentais das comunidades remanescentes de quilombo", 2015.

Os resultados mais importantes do evento podem ser sumarizados a seguir: 1) a identificação da existência da comunidade quilombola de Queimadas na Área de Influência Direta (AID) do empreendimento minerário; 2) a demonstração da necessidade de realização de consulta livre, prévia e informada da comunidade quilombola de Queimadas, em estrito cumprimento das normas jurídicas constantes nos artigos 6, 7 e 15 da Convenção n. 169 da Organização Internacional do Trabalho; 3) a mobilização da comunidade local para a compreensão dos impactos socioambientais a serem provocados com a instalação do empreendimento minerário, especialmente em relação às formas de uso e ocupação consolidadas no município do Serro; 4) a identificação de que o empreendimento minerário se situa em área de recarga hídrica das bacias do Rio do Peixe e do Rio Guanhães; e, 5) a identificação de que a área de influência direta do empreendimento minerário se sobrepõe, parcialmente, à zona de amortecimento do Parque Estadual do Pico do Itambé.

No dia 16 de setembro de 2015, foi realizada reunião ordinária do CODEMA, com a participação de representantes legais da empresa mineradora e de lideranças da comunidade quilombola de Queimadas. Os representantes legais da empresa mineradora fizeram uma exposição do EIA/RIMA referente ao empreendimento minerário, especialmente em relação à localização e tipo de empreendimento que se pretende instalar e operar no local. Por sua vez, as lideranças da comunidade quilombola de Queimadas mostraram, no mapa cartográfico apresentado pela empresa mineradora, que a comunidade está localizada na Área de Influência Direta (AID) do empreendimento minerário. A seguir, os membros do CODEMA questionaram sobre a existência de 
sobreposição entre a Área de Influência Direta (AID) do empreendimento minerário e a zona de amortecimento do Parque Estadual do Pico do Itambé; do impacto sobre as bacias do Rio do Peixe e do Rio Guanhães; da infraestrutura viária a ser utilizada para o escoamento do minério de ferro extraído; e sobre a sobreposição entre a Área de Influência Direta (AID) e o território da comunidade quilombola de Queimadas.

Em Ofício datado do dia 08 de outubro de 2015, encaminhado ao CODEMA, empresa mineradora reconheceu que "há evidências da presença de uma comunidade quilombola (ou parte dela) dentro do raio de $8 \mathrm{~km}$ do projeto, distância definida pela portaria interministerial 60/2015 como área de influência de empreendimentos pontuais sobre comunidades tradicionais, fora da Amazônia Legal”.

A partir do reconhecimento formal da empresa mineradora de que o empreendimento minerário se sobrepunha ao território da comunidade quilombola de Queimadas, o CODEMA exigiu a instauração de um procedimento de consulta livre, prévia e informada dos órgãos representativos da comunidade quilombola de Queimadas, com a finalidade de promover uma discussão democrática sobre a adaptação do empreendimento minerário aos interesses da comunidade quilombola.

O direito à consulta livre, prévia e informada está previsto nos artigos $6^{\circ}, 7^{\circ}$ e 15 da Convenção n. 169 da Organização Internacional do Trabalho (OIT), que foi promulgada pelo Decreto n. ${ }^{\circ} 5.051$, de 19 de abril de 2004:

Artigo $6^{\circ}$.

1. Ao aplicar as disposições da presente Convenção, os governos deverão:

a) consultar os povos interessados, mediante procedimentos apropriados e, particularmente, através de suas instituições representativas, cada vez que sejam previstas medidas legislativas ou administrativas suscetíveis de afetá-los diretamente;

2. As consultas realizadas na aplicação desta Convenção deverão ser efetuadas com boa fé e de maneira apropriada às circunstâncias, com o objetivo de se chegar a um acordo e conseguir o consentimento acerca das medidas propostas.

Artigo $7^{\circ}$.

1. Os povos interessados deverão ter o direito de escolher suas, próprias prioridades no que diz respeito ao processo de desenvolvimento, na medida em que ele afete as suas vidas, crenças, instituições e bem-estar espiritual, 
bem como as terras que ocupam ou utilizam de alguma forma, e de controlar, na medida do possível, o seu próprio desenvolvimento econômico, social e cultural. Além disso, esses povos deverão participar da formulação, aplicação e avaliação dos planos e programas de desenvolvimento nacional e regional suscetíveis de afetá-los diretamente.

$[\ldots]$

Artigo 15

1. Os direitos dos povos interessados aos recursos naturais existentes nas suas terras deverão ser especialmente protegidos. Esses direitos abrangem o direito desses povos a participarem da utilização, administração e conservação dos recursos mencionados.

2. Em caso de pertencer ao Estado a propriedade dos minérios ou dos recursos do subsolo, ou de ter direitos sobre outros recursos, existentes nas terras, os governos deverão estabelecer ou manter procedimentos com vistas a consultar os povos interessados, a fim de se determinar se os interesses desses povos seriam prejudicados, e em que medida, antes de se empreender ou autorizar qualquer programa de prospecção ou exploração dos recursos existentes nas suas terras. Os povos interessados deverão participar sempre que for possível dos benefícios que essas atividades produzam, e receber indenização equitativa por qualquer dano que possam sofrer como resultado dessas atividades.

O direito à consulta livre, prévia e informada possui a finalidade de instituir um procedimento equitativo destinado a assegurar a compatibilização dos interesses e da forma de vida das comunidades quilombolas com os interesses do empreendedor econômico e das outras classes e grupos étnicos formadores da sociedade brasileira.

Assim, no procedimento de consulta, discute-se a adaptação do empreendimento econômico para atender os desejos, interesses e valores das comunidades quilombolas, bem como assegurar o respeito e a preservação de sua forma de vida. Por isso, não é lícito apresentar o projeto de empreendimento econômico, sem que seja possível adaptá-lo aos interesses e à forma de vida dos povos e comunidades tradicionais.

Nesse sentido, Deborah Duprat (2014, p. 64) explica o significado do direito à consulta livre, prévia e informada, nos seguintes termos:

A consulta é prévia exatamente porque é de boa-fé e tendente a chegar a um acordo. Isso significa que, antes de iniciado o processo decisório, as partes se colocam em um diálogo que permita, por meio de revisão de suas posições iniciais, se chegar à melhor decisão. Desse modo, a consulta traz em si, ontologicamente, a possibilidade de revisão do projeto inicial ou mesmo de sua não realização. Aquilo que se apresenta como já decidido não enseja, logicamente, consulta, pela sua impossibilidade de gerar qualquer reflexo na decisão. A Resolução CONAMA n ${ }^{\circ} 1$, de 23 de janeiro de1986, que "dispõe sobre critérios básicos e diretrizes gerais para a avaliação de impacto ambiental", diz, em seu art. $5^{\circ}$, I, que o estudo de 
impacto ambiental deve "contemplar todas as alternativas tecnológicas e de localização do projeto, confrontando-as com a hipótese de não execução do projeto". Esse é um norte bastante adequado também para a consulta, inclusive naqueles casos em que se exige prévia autorização do Congresso Nacional. A Convenção 169 não deixa dúvidas quanto a esse ponto: a consulta antecede quaisquer medidas administrativas e legislativas com potencialidade de afetar diretamente povos indígenas e tribais.

Também decorre da racionalidade do sistema que, nas medidas que se desdobram em vários atos, como ocorre, por exemplo, no procedimento de licenciamento ambiental, a consulta prévia seja renovada a cada geração de novas informações, especialmente aquelas relativas a impactos a serem suportados pelos grupos. O consentimento inicial para a obra se dá a partir dos poucos dados disponíveis. Uma vez realizado o estudo de impacto ambiental e adicionadas outras tantas informações, a consulta tem que ser renovada, e, mais uma vez, iniciado o processo dialógico tendente ao acordo.

Esse é um imperativo que decorre, primeiro, dos próprios vetores da consulta (especialmente, nesse ponto, o seu caráter de boa fé), e, segundo, da natureza do estudo de impacto ambiental. Esse estudo, nos termos do art. $6^{\circ}$ da Resolução CONAMA 001/86, deve fazer (i) o diagnóstico da área de influência do projeto sob três perspectivas - meios físico, biótico e socioeconômico, e as interações entre eles; (ii) a análise dos impactos ambientais do projeto e suas alternativas; (iii) a definição das medidas mitigadoras dos impactos negativos. É o conjunto dessas informações que habilitará os grupos impactados a decidirem pela realização ou não da obra, ou pela adoção de projeto alternativo. Não seria razoável conclusão no sentido de que aquela primeira adesão, feita com base em informações um tanto quanto precárias, pela ausência dos estudos cabíveis, esgotasse o processo de consulta da Convenção 169. Portanto, é imperativo considerar que a consulta é de natureza procedimental sempre que a medida projetada assim se apresentar, e se renova a cada fase do procedimento que agregar novas informações sobre impactos a serem suportados pelos grupos diretamente atingidos, bem como sobre as medidas tendentes a mitigá-los e compensá-los.

A consulta também pressupõe que nenhuma, absolutamente nenhuma, fase da obra se inicie antes que estejam disponíveis todos os dados técnicos acima referidos, que permitam aos grupos se posicionarem nesse processo dialógico. A despeito da obviedade da assertiva, o que se vem observando, no Brasil, é que muitas das informações que deveriam constar do diagnóstico só são produzidas mais tardiamente, como condicionantes das licenças de instalação e de operação. Assim a obra, no mais das vezes, chega à fase final sem que os grupos tenham acesso à principal informação que os capacitaria a uma decisão consequente: a avaliação dos impactos do empreendimento sobre eles próprios. É evidente a subversão do processo de consulta em seus três pilares: deixa de ser prévia, de boa fé e dialógica.

A análise de conjuntura, feita por meio do diálogo entre os professores e alunos dos projetos de extensão da PUC-Minas e as lideranças quilombolas de Queimadas, indicou a necessidade de se exigir a realização de estudos complementares ao EIA/RIMA, com a finalidade de descrever, pormenorizadamente, os impactos à forma de vida 
quilombola, em especial aos aspectos sociais, econômicos e culturais, que seriam causados pela implantação do empreendimento minerário. Os estudos complementares deveriam, também, indicar as medidas mitigadoras/compensatórias, que seriam realizadas pela empresa mineradora.

E, apenas no momento em que a empresa mineradora apresentasse os estudos complementares ao EIA/RIMA, com as informações necessárias para a perfeita compreensão dos impactos do empreendimento minerário à forma de vida da comunidade quilombola de Queimadas, os órgãos representativos da comunidade manifestariam sua concordância, ou não, com a implantação do empreendimento minerário.

Contudo, no dia 21 de outubro de 2015, em reunião ordinária do CODEMA, a empresa mineradora se recusou a participar de qualquer procedimento de consulta aos órgãos representativos da comunidade quilombola de Queimadas. A empresa mineradora expressou que não promoveria qualquer adaptação ao empreendimento minerário e, por isso, a consulta seria inócua e sem consequências práticas concretas.

Diante da postura intransigente da empresa mineradora, foi marcada reunião extraordinária para o dia 28 de outubro de 2015, com o objetivo exclusivo de deliberar sobre a recomendação ao Prefeito Municipal sobre a emissão, ou não, da Certidão de Conformidade do Projeto Serro às Leis de Uso e Ocupação do Solo.

Nos dias anteriores à reunião extraordinária designada para a deliberação sobre a recomendação ao Prefeito Municipal sobre a emissão, ou não, da Certidão de Conformidade do Projeto Serro às Leis de Uso e Ocupação do Solo, os representantes legais da empresa mineradora procuraram os membros do CODEMA e, de modo hostil e intimidador, disseram que a manifestação contrária ao empreendimento minerário poderia acarretar prejuízos ao município e aos próprios conselheiros.

No dia 28 de outubro de 2015, o CODEMA realizou reunião extraordinária, com o objetivo exclusivo de deliberar sobre a recomendação ao Prefeito Municipal sobre a declaração de (des)conformidade socioambiental do empreendimento minerário. A reunião foi iniciada com a exposição da empresa mineradora do empreendimento minerário por ela proposto. A seguir, a palavra foi aberta ao público em geral, assegurando que toda e qualquer pessoa pudesse apresentar suas opiniões, dúvidas e questionamentos sobre o empreendimento minerário. E, no final, os membros do CODEMA deliberaram, de forma unânime, pela desconformidade socioambiental do empreendimento minerário. 
É importante destacar, aqui, que a decisão do CODEMA foi tomada de modo unânime, sendo que os representantes do IEF, da Polícia Militar Ambiental, da Associação Comercial do Serro, da PUC-Minas, da Câmara de Vereadores, do Sindicato dos Trabalhadores Rurais e da Secretaria de Meio Ambiente do Município votaram no sentido de se declarar a desconformidade socioambiental do empreendimento minerário.

A partir dos dados concretos do processo de discussão e deliberação sobre a desconformidade socioambiental do empreendimento minerário, é possível afirmar que o CODEMA assegurou a mais ampla participação de todos os grupos étnicos e classes sociais constituidores da sociedade serrana, atuando para condicionar o projeto de empreendimento minerário ao atendimento dos interesses e valores dos diversos grupos sociais.

Assim, numa sociedade em que predomina, ainda, relações de colonialidade, na qual grupos étnicos subalternizados são desrespeitados, desconsiderados e silenciados nos processos de tomada de decisões coletivamente obrigatórias ${ }^{12}$, o CODEMA exigiu a

\footnotetext{
12 A ordem social na América foi construída com base na ideia de raça, que funciona como critério de definição da posição social das pessoas nas relações políticas, sociais e econômicas. Na arquitetura social instituída na América, os povos indígenas (como povos originários da América) e os povos africanos (como povos introduzidos na América na condição de escravos) se situam na posição de subalternização política e econômica, submetidos aos interesses e à vontade das classes e grupos étnicos dominantes, por meio da naturalização das relações de colonialidade operativas nas sociedades latino-americanas. Nesse sentido, Aníbal Quijano (2014, pp. 285/286) afirma que: "la colonialidad es uno de los elementos constitutivos y específicos del patrón mundial de poder capitalista. Se funda en la imposición de una clasicación racial/étnica de la población del mundo como piedra angular de dicho patrón de poder, y opera en cada uno de los planos, ámbitos y dimensiones, materiales y subjetivas, de la existencia cotidiana y a escala social. Se origina y mundializa a partir de América. Con la constitución de América (Latina), en el mismo momento y en el mismo movimiento histórico, el emergente poder capitalista se hace mundial, sus centros hegemónicos se localizan en las zonas situadas sobre el Atlántico - que después se identificarán como Europa-, y como ejes centrales de su nuevo patrón de dominación se establecen también la colonialidad y la modernidad. En otras palabras: con América (Latina) el capitalismo se hace mundial, eurocentrado y la colonialidad y la modernidad se instalan, hasta hoy, como los ejes constitutivos de este específico patrón de poder. En el curso del despliegue de esas características del poder actual, se fueron configurando las nuevas identidades sociales de la colonialidad (indios, negros, aceitunados, amarillos, blancos, mestizos) y las geoculturales del colonialismo (América, África, Lejano Oriente, Cercano Oriente, Occidente y Europa). Las relaciones intersubjetivas correspondientes, en las cuales se fueron fundiendo las experiencias del colonialismo y de la colonialidad con las necesidades del capitalismo, se fueron configurando como un nuevo universo de relaciones intersubjetivas de dominación bajo la hegemonía eurocentrada. Ese específico universo es el que será después denominado modernidade”. Assim, o fim da dominação colonial da Europa sobre a América, por meio do processo de independência política dos países latino-americanos, não ocasionou o fim das relações de colonialidade. Pelo contrário, as relações de colonialidade se perpetuam até os dias atuais, mostrando-se em nossas relações políticas e econômicas. Nesse sentido, Aníbal Quijano (2014, p. 285) afirma que: "Colonialidad es un concepto diferente, aunque vinculado con el concepto de colonialismo. Este último se refiere estrictamente a una estructura de dominación y explotación, donde el control de la autoridad política, de los recursos de producción y del trabajo de una población determinada lo detenta otra de diferente identidad, y cuyas sedes centrales están, además, en otra jurisdicción territorial. Pero no siempre, ni necesariamente, implica relaciones racistas de poder. El colonialismo es, obviamente, más antiguo, en tanto que la colonialidad ha probado ser, en los últimos quinientos años, más profunda y
} 
consulta livre, prévia e informada, com a obtenção do consentimento dos órgãos representativos da comunidade quilombola de Queimadas, em ruptura com as práticas racistas e coloniais ainda existentes no Estado brasileiro.

Em outras palavras, na tentativa de construir uma discussão e deliberação genuinamente democrática, na qual todas as pessoas, grupos étnicos e classes sociais pudessem influenciar a tomada de decisões coletivamente obrigatórias, neutralizando, na maior medida do possível, o racismo e a colonialidade que caracterizam a sociedade civil e do Estado no Serro, o CODEMA assegurou a igual participação política de todos os serranos, inclusive dos grupos subalternizados, que, pela primeira vez, tiveram voz e vez no processo de tomada de decisões.

Assim, a crítica procedimental é uma mistificação do que foi o processo de discussão e deliberação sobre a implantação do empreendimento minerário na cidade do Serro. A referida crítica é a expressão de um conjunto de ideias, que, a pretexto de representar o modo de ser das coisas, distorce a realidade, de modo a ocultar a ampla participação popular na tomada de decisão pela declaração de desconformidade socioambiental do empreendimento minerário. A referida crítica oculta, também, que a empresa mineradora sabotou, de todas as maneiras possíveis, a efetiva participação popular no processo de tomada de decisão ${ }^{13}$.

No lugar da realidade do processo de discussão e deliberação sobre a desconformidade socioambiental do empreendimento minerário, a crítica procedimental cria uma imagem fantasiosa e distorcida do referido processo, com o intuito de deslegitimar a decisão democraticamente tomada por toda a população do Serro.

duradera que el colonialismo. Pero sin duda fue engendrada dentro de éste y, más aún, sin él no habría podido ser impuesta en la intersubjetividad del mundo, de modo tan enraizado y prolongado".

${ }^{13}$ As críticas formuladas à decisão do CODEMA se enquadram no conceito de ideologia, que foi exposto por Marilena Chaú $(2008$, p. 8) nos seguintes termos: "Frequentemente, ouvimos expressões do tipo 'partido político ideológico', é preciso ter uma 'ideologia', 'falsidade ideológica'. Essas expressões tomam a palavra ideologia para com ela significar 'conjunto sistemático e encadeado de ideias'. Ou seja, confundem ideologia com ideário. Nossa tarefa, aqui, será desfazer a suposição de que a ideologia é um ideário qualquer ou qualquer conjunto encadeado de ideias e, ao contrário, mostrar que a ideologia é um ideário histórico, social e politico que oculta a realidade, e que esse ocultamento é uma forma de assegurar e manter a exploração econômica, a desigualdade social e a dominação política". E, a seguir, a filósofa explica a função da ideologia na manutenção das relações de dominação existentes: "Em sociedades divididas em classes (e também em castas), nas quais uma das classes explora e domina as outras, essas explicações ou essas ideias e representações serão produzidas e difundidas pela classe dominante para legitimar e assegurar seu poder econômico, social e político. Por esse motivo, essas ideias ou representações tenderão a esconder dos homens o modo real como suas relações sociais foram produzidas e a origem das formas sociais de exploração econômica e de dominação política. Esse ocultamento da realidade social chama-se ideologia. Por seu intermédio, os dominantes legitimam as condições sociais de exploração e de dominação, fazendo com que pareçam verdadeiras e justas" (CHAUÍ, 2008, p. 24). 
A crítica procedimental se baseia no critério de que são democráticas apenas as decisões estatais que atendam aos interesses do capital, reduzindo o Estado a um mero "comitê para gerir os negócios comuns de toda a classe burguesa" (MARX, 2017, p. 24).

Assim, toda e qualquer decisão estatal, que não atenda aos interesses da acumulação do capital, é qualificada como a expressão “[...] de um 'líder carismático’ (ou alguns) a falar em nome de um "povo do Serro"”; como "ultrapassada, ilegítima e antidemocrática"; ou, como a demonstração do "despreparo dos gestores no trato democrático" de questões práticas relevantes como a mineração.

Nota-se, então, que a concepção de democracia implícita na crítica procedimental expressa, na verdade, a defesa de uma ditadura do capital, na medida em que é qualificada como democrática apenas a decisão estatal que atenda aos interesses de acumulação do capital, desprezando e silenciando interesses antagônicos de outras classes e grupos étnicos.

Por mais que o procedimento administrativo tenha assegurado a participação igualitária de todas as pessoas, classes e grupos étnicos, inclusive dos grupos subalternizados pela perpetuidade das relações de colonialidade que marcam a sociedade serrana; por mais que se tenha exigido a adaptação do projeto de mineração ao atendimento dos interesses das classes e grupos étnicos subalternizados que constituem a sociedade serrana, a decisão estatal contrária aos interesses de acumulação do capital será qualificada como "ilegítima", "antidemocrática", arbitrária”, como está expresso na crítica procedimental.

Por isso, os críticos expressam a sua esperança de que "a questão da mineração da cidade do Serro/MG poderia e deveria ser mais e melhor debatida", propondo uma reabertura da discussão e deliberação sobre o empreendimento minerário denominado "Projeto Serro", até que uma decisão favorável ao capital seja proferida. Pouco importa que o CODEMA tenha promovido discussões sobre o empreendimento minerário, com participação das diversas classes e grupos étnicos que compõem a sociedade serrana, durante todo o ano de 2015. Pouco importa, também, que a deliberação do CODEMA tenha sido tomada por representantes de diversas classes e grupos étnicos, bem como por representantes de diversos órgãos estatais. O que importa é repetir as discussões e as deliberações até que, enfim, os interesses da acumulação do capital prevaleçam sobre todos os demais interesses das classes e grupos étnicos formadores da sociedade serrana. 
O projeto de extensão "A luta pelo reconhecimento dos direitos fundamentais das comunidades remanescentes de quilombo" possui uma compreensão diferente de democracia. Nas atividades de extensão, promove-se a participação dos grupos subalternizados pelas relações de colonialidade existentes nos processos de tomada de decisões coletivamente obrigatórias, por meio da tomada de consciência de seus interesses materiais e valores simbólicos e da exigência de que estes interesses e valores sejam respeitados pelas decisões estatais. O caráter democrático de uma decisão estatal é medido pelo respeito aos interesses e valores dos grupos subalternizados e não pela acumulação do capital, cujo atendimento é quase que naturalizado nas decisões do Estado moderno.

Ora, a declaração de desconformidade socioambiental do empreendimento minerário denominado "Projeto Serro" é a expressão genuína da mais ampla participação democrática das diversas classes e grupos étnicos formadores da sociedade serrana, na decisão sobre o modelo de desenvolvimento econômico a ser adotado pelo município do Serro. E, o mais importante, o CODEMA condicionou a autorização do empreendimento minerário ao atendimento das demandas dos grupos subalternizados, exigindo-se, assim, a construção de um verdadeiro consenso democrático no qual a decisão estatal expresse, de modo genuíno, o interesse comum de todas as classes e grupos étnicos formadores da sociedade serrana.

Por isso, ao contrário da esperança expressada pelos críticos da decisão do CODEMA, o projeto de extensão "A luta pelo reconhecimento dos direitos fundamentais das comunidades remanescentes de quilombo" espera que o município do Serro respeite a declaração de desconformidade socioambiental do empreendimento minerário denominado "Projeto Serro", resguardando os interesses dos grupos subalternizados e não cedendo à imposição colonialista dos interesses de acumulação do capital.

\section{RESPOSTA À CRÍTICA DE CONTEÚdO: A PONDERAÇÃO DAS EXTERNALIDADES POSITIVAS E NEGATIVAS DECORRENTES DO EMPREENDIMENTO MINERÁRIO.}

A crítica de conteúdo sustenta, em síntese, que a decisão do CODEMA desconsiderou os eventuais benefícios proporcionados pela implantação do 
empreendimento minerário, tais como, "o aumento da renda per capita do município", "o aumento da arrecadação de impostos municipais", "o aquecimento do comércio de produtos e serviços locais", "o aumento da oferta de empregos", “a redução da informalidade trabalhista", "a valorização dos imóveis urbanos e rurais", "uma melhor distribuição de renda" e "o aumento de oportunidades econômico-financeiro-culturalsocial".

$\mathrm{Na}$ perspectiva dos críticos da decisão do CODEMA, a implantação do empreendimento minerário na cidade do Serro proporcionaria um aumento nas oportunidades de emprego da região, com melhoria da renda da população, e na arrecadação de tributos do município. Entretanto, os críticos não apresentam quaisquer dados concretos para amparar as suas previsões da promoção dos benefícios por eles indicados, no caso de implantação do empreendimento minerário.

É preciso, então, apresentar os dados concretos do empreendimento minerário denominado "Projeto Serro", com a indicação da dimensão do empreendimento econômico, da estimativa de duração do empreendimento e da estimativa de mão-de-obra a ser utilizada pelo empreendimento. E, com base em dados concretos do empreendimento minerário, analisar a verdade/falsidade da crítica de conteúdo.

O empreendimento minerário denominado "Projeto Serro" consiste em lavra de minério de ferro, em escala de produção de 500.000 toneladas/ano, e posterior beneficiamento a seco, com duração estimada em 17 anos, contando as fases de planejamento, implantação, operação e desativação do empreendimento minerário (EIA, volume 1, pp. 13/27).

O tempo de execução da lavra de minério de ferro é estimado em 10 anos. Ou seja, este é o período em que as riquezas serão efetivamente produzidas, com a possibilidade de aumento na arrecadação municipal por meio da cobrança da Compensação Financeira pela Exploração de Recursos Minerais (CFEM).

O cronograma geral do empreendimento minerário, contando com as fases de planejamento, implantação, operação e desativação do projeto, pode ser visualizado no quadro a seguir reproduzido, que consta no EIA/RIMA, volume 1, p. 27: 
Quadro 2.1-7: Cronograma Geral do Projeto Serro.

\begin{tabular}{|c|c|c|c|c|c|c|c|c|c|c|c|c|c|c|c|c|c|c|c|c|c|c|c|c|c|c|}
\hline \multirow{3}{*}{ ATIVIDADE } & \multicolumn{25}{|c|}{ ESTIMATIVA DE TEMPO (Anos) } & \\
\hline & \multicolumn{3}{|c|}{ Ano 1} & \multicolumn{3}{|c|}{ Ano 2} & \multicolumn{3}{|c|}{ Ano 3} & \multicolumn{2}{|c|}{ Ano 4} & \multirow{2}{*}{\multicolumn{2}{|c|}{5}} & \multirow{2}{*}{6} & \multirow{2}{*}{7} & \multirow{2}{*}{8} & \multirow{2}{*}{9} & \multirow{2}{*}{0} & \multirow{2}{*}{10} & \multirow{2}{*}{11} & \multirow{2}{*}{12} & \multirow{2}{*}{13} & \multirow{2}{*}{14} & \multirow{2}{*}{15} & \multirow{2}{*}{16} & \multirow{2}{*}{17} \\
\hline & 1 & 23 & 4 & 1 & 2 & 3 & 1 & \begin{tabular}{|l|l|}
2 & 3 \\
\end{tabular} & 4 & $1:$ & \begin{tabular}{|l|l|}
2 & 3 \\
\end{tabular} & & & & & & & & & & & & & & & \\
\hline \multicolumn{27}{|l|}{ FASE DE PLANEJAMENTO } \\
\hline \multicolumn{27}{|l|}{$\begin{array}{c}\text { Elaboração dos Estudos Ambientais } \\
\text { para obtenção da LP* }\end{array}$} \\
\hline \multicolumn{27}{|l|}{ FASE DE IMPLANTAÇÃO } \\
\hline \multicolumn{27}{|l|}{ Requerimento e Obtenção da LI } \\
\hline \multicolumn{27}{|l|}{$\begin{array}{l}\text { Instalação do canteiro de obras, } \\
\text { Montagem das estruturas e } \\
\text { desmobilização do canteiro }\end{array}$} \\
\hline \multicolumn{27}{|l|}{ FASE DE OPERAÇÃO } \\
\hline \multicolumn{27}{|l|}{$\begin{array}{l}\text { Requerimento e Obtenção da Portaria } \\
\text { de Lavra }\end{array}$} \\
\hline \multicolumn{27}{|l|}{ Requerimento e Obtenção da LO } \\
\hline Execução da lavra & & & & & & & & & & & & & & & & & & & & & & & & & & \\
\hline FASE DE DESATIVAÇÃO & & & & & & & & & & & & & & & & & & & & & & & & & & \\
\hline Planejamento & & & & & & & & & & & & & & & & & & & & & & & & & & \\
\hline Descomissionamento da mina & & & & & & & & & & & & & & & & & & & & & & & & & & \\
\hline
\end{tabular}

Fonte: Anglo American Minério de Ferro do Brasil S.A., 2014.

O "Projeto Serro" é empreendimento minerário de pequeno porte, com reduzida capacidade de produção de minério de ferro dos tipos NPO (natural pellet ore) e hematitinha. A viabilidade econômica da exploração minerária é justificada pelo elevado teor de pureza das reservas minerárias encontradas. Ou seja, apesar de o volume de minério de ferro ser pequeno, o "seu elevado teor de pureza viabiliza economicamente a exploração das reservas como fonte de matéria-prima para abastecimento do parque siderúrgico nacional” (EIA/RIMA, 2014, volume 1, p. 67).

Nesse sentido, o EIA/RIMA (2014, volume 1, p. 17) caracteriza o empreendimento minerário da seguinte forma:

O Projeto Serro possui a particularidade de ser um empreendimento com regime de produção em escala relativamente reduzida, em nível experimental. Esta atividade é fundamental para a empresa testar, em escala industrial, as características do minério local, o que possibilitará a identificação dos diferentes tipos de produtos finais a serem gerados, suas proporções e a aceitação destes produtos no mercado consumidor do país.

Por ser um empreendimento minerário experimental e com regime de produção em escala relativamente reduzida, será reduzido, também, os tributos e empregos a serem gerados pela implantação da mineração. E, considerando que a estimativa de duração do empreendimento minerário é de 17 anos, contadas as fases de planejamento, instalação, 
operação e desativação do empreendimento minerário, pode-se afirmar, então, que o período de existência das vagas de trabalho será, também, muito reduzido.

Assim, duração a fase de implantação do empreendimento minerário ${ }^{14}$, com duração aproximada de 1 ano e 2 meses, estima-se a geração de, no máximo, 300 vagas de trabalho assalariado, a serem alocados nas áreas de apoio administrativo e nas obras, para o exercício de funções de baixa remuneração (EIA/RIMA, 2014, volume 1, p. 44). O quadro abaixo (EIA/RIMA, volume 1, 2014, p. 44) representa o número de empregos gerados na fase de implantação do empreendimento minerário:

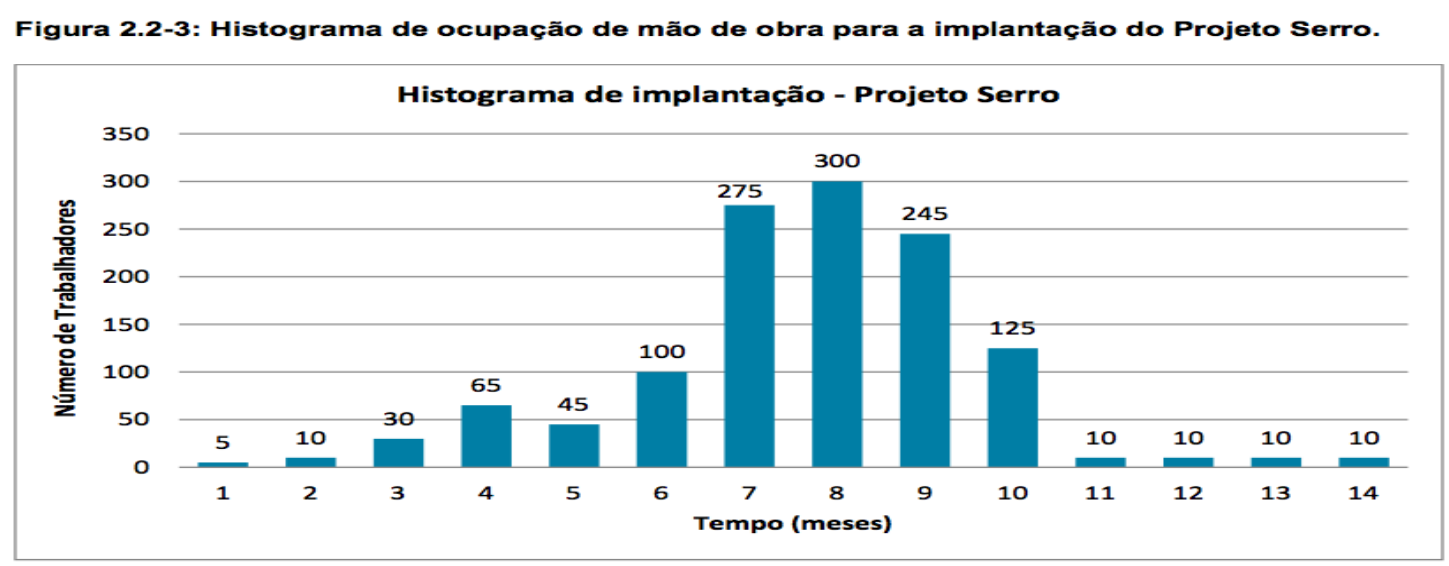

Fonte: Anglo American Minério de Ferro do Brasil S.A., 2014.

A partir da fase de operação ${ }^{15}$, com duração estimada em 10 anos, o número de empregos, diretos e indiretos, gerados pelo empreendimento minerário, será inferior a 200 vagas, com recrutamento de mão-de-obra operacional e administrativa, que, formalmente, será submetida ao regime de trabalho "de 2 turnos, com paradas aos domingos, respeitando um regime máximo de trabalho de 220h/mês" (EIA/RIMA, volume 1, 2014, p. 83).

O quadro abaixo (EIA/RIMA, volume 1, 2014, p. 85) representa o número de empregos gerados na fase de operação do empreendimento minerário:

\footnotetext{
14 “A fase de implantação do empreendimento constitui-se no momento em que será construída ou melhorada toda a infraestrutura necessária para permitir a operação do futuro empreendimento". (EIA/RIMA, volume 1, 2014, p. 28).

15 "Na fase de operação do presente empreendimento está prevista a realização de atividades de lavra e beneficiamento do minério por meio de operações de fragmentação e classificação granulométrica a seco" (EIA/RIMA, volume 1, 2014, p. 62).
} 
Figura 2.2-16: Histograma de Ocupação da Mão de Obra.

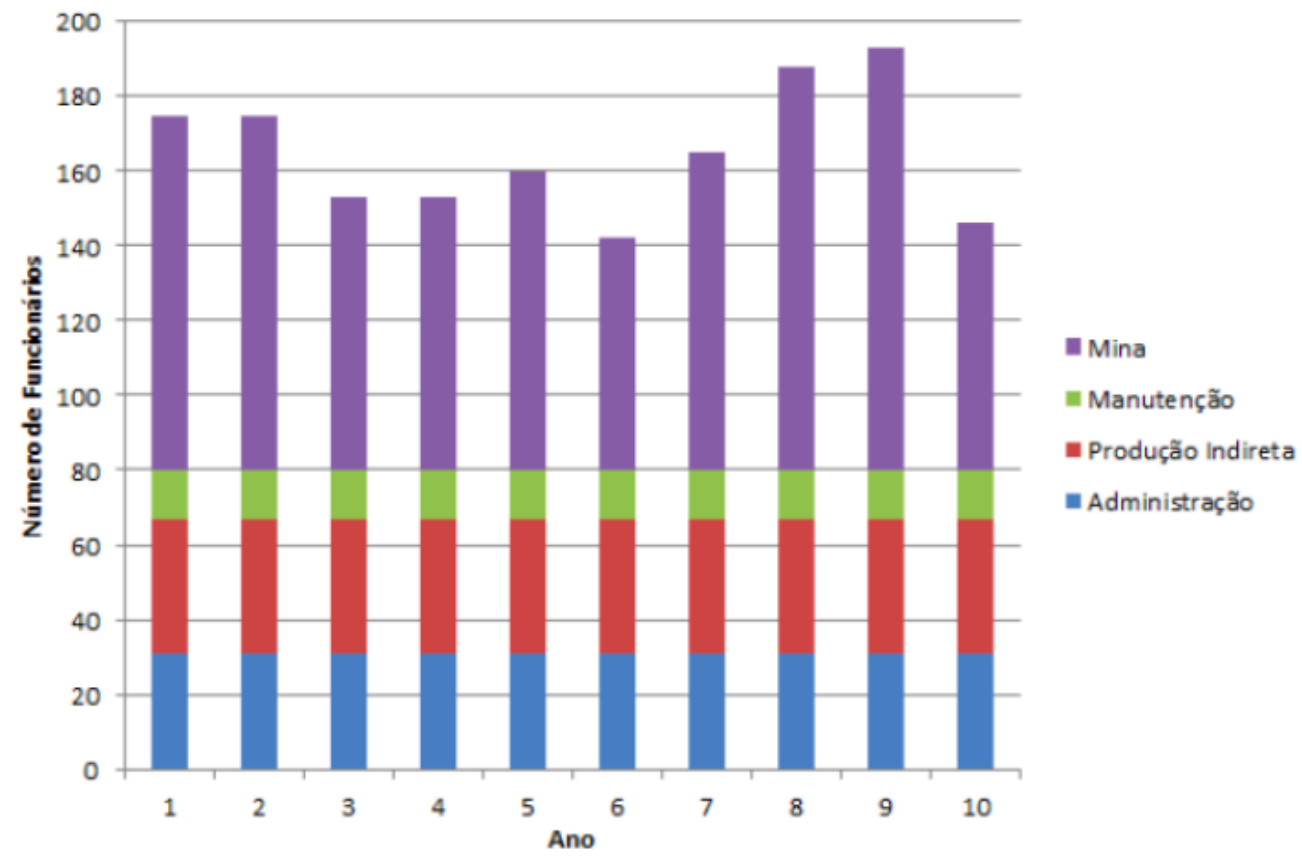

Fonte: Geomil Serviços de Mineração, 2011.

Além de ser reduzido o número de empregos a serem proporcionados pelo empreendimento minerário, esses empregos são, em sua grande maioria, de baixa remuneração e submetem os trabalhadores a condições degradantes e análogas às de escravo.

Pois, a partir da experiência proporcionada pela implantação de empreendimento minerário, por parte da Anglo American Minério de Brasil S.A., na cidade de Conceição do Mato Dentro, que é vizinha da cidade do Serro e fica a uma distância de $60 \mathrm{~km}$, constatou-se o uso intensivo de mão-de-obra sujeita à condição análoga à escravidão.

Assim, as empresas terceirizadas indicadas no quadro abaixo, que foram contratadas pela Anglo American Minério de Ferro Brasil S.A. para prestarem serviços na implantação da mina de minério de ferro na cidade de Conceição do Mato Dentro, submeteram inúmeros trabalhadores a condições análogas a de escravo, por meio da exigência de jornada de trabalho excessiva, condições degradantes dos alojamentos e da alimentação fornecidos pelos empregadores, dentre outros motivos.

De acordo com a lista de empregadores flagrados administrativamente submetendo trabalhadores a condições análogas às de escravo, e cujos processos 
administrativos de autos de infração já foram regularmente processados e decididos no âmbito do contencioso administrativo trabalhista até o ano de $2016^{16}$, constam as seguintes informações:

\begin{tabular}{|c|c|c|c|c|c|c|c|c|}
\hline & ANo & UF & EMPREGADOR & CNPJ/CPF & ESTABELECIMENTO & CNAE & $\begin{array}{l}\text { DECISÃo } \\
\text { ADIINISTRATIVA } \\
\text { FINAL }\end{array}$ & $\begin{array}{c}\text { TRAB. } \\
\text { ENYOL } \\
\text {. }\end{array}$ \\
\hline 71 & 2014 & MG & Construtora Modelo Ltda & $41.801 .440 / 0001-25$ & $\begin{array}{l}\text { Fazenda Jardim - São Sebastião do Bom } \\
\text { Sucesso, Conceição do Mato Dentro/MG }\end{array}$ & $4120-4 / 00$ & $04 / 08 / 2015$ & 19 \\
\hline 101 & 2014 & MG & Enesa Engenharia & $48.785 .828 / 0001-29$ & $\begin{array}{l}\text { Obra de implantação de mina - } \\
\text { Conceição do Mato Dentro/MG }\end{array}$ & $4292-8 / 02$ & $17 / 04 / 2016$ & 53 \\
\hline 250 & 2014 & MG & $\begin{array}{l}\text { Milplan - Engenharia } \\
\text { Construçōes e } \\
\text { Montagens Ltda }\end{array}$ & $17.521 .519 / 0001-18$ & $\begin{array}{l}\text { Obra de implantação de mina - } \\
\text { Conceição do Mato Dentro/MG }\end{array}$ & $4292-8 / 02$ & 05/08/2015 & 46 \\
\hline
\end{tabular}

Fonte: Ministério do Trabalho, 2016.

No ano de 2014, o Ministério Público do Trabalho (MPT) e a Polícia Federal (PF) resgataram 160 trabalhadores, dentre os quais estavam 100 haitianos e 60 nordestinos, que haviam sido vítimas dos crimes de tráfico de pessoas e submissão de trabalhador à condição análogo a de escravo, e que trabalhavam em empresas terceirizadas pela Anglo American Minério de Ferro Brasil S.A, para prestarem serviços em atividades ligadas à mineração implantada na cidade de Conceição do Mato Dentro. Assim, o Ministério Público do Trabalho divulgou a seguinte notícia, disponível em https://mpt.jusbrasil.com.br/noticias/112109410/obra-da-anglo-american-e-flagradacom-trafico-de-pessoas:

Força Tarefa do Ministério Público do Trabalho (MPT), Ministério do Trabalho e da Polícia Federal resgatou 160 trabalhadores vítimas do tráfico de pessoas e em condições degradantes em uma obra da construtora Diedro no município Conceição do Mato Dentro (MG), a 167 km de Belo Horizonte. São 100 haitianos e 60 nordestinos aliciados nos estados de Sergipe, Pernambuco e Piauí, que trabalhavam na construção de casas para os futuros empregados da Anglo American, uma das maiores mineradoras do mundo. A operação começou no dia 4 deste mês e terminou nesta quinta-feira (14).

Até ontem foram feitas mais de 140 rescisões indiretas, com base em termo de ajustamento de conduta (TAC) firmado com o MPT. O TAC prevê tanto indenização individual de $\mathrm{R}$ \$ 22 mil, quanto dano moral de $\mathrm{R}$ \$ 1 milhão para ser aplicado em atividades esportivas no tempo livre do trabalhador emigrante. A caracterização do tráfico de pessoas no território nacional deu-se tão somente em relação aos trabalhadores nordestinos. Eles já retornaram de ônibus as suas cidades de origem.

Os haitianos foram transportados do Acre para Minas Gerais com a documentação e da forma corretas, mas foram resgatados em decorrência das condições degradantes. Eles foram liberados para retornarem ao Acre.

16 Disponível em: http://reporterbrasil.org.br/wp-content/uploads/2016/12/listadetransparencia4.pdf. Acesso em 25/02/2018, às 11:35. 


\begin{abstract}
"O resgate vai trazer benefícios não só para os trabalhadores mas também para a cidade de Conceição do Mato Dentro, que ficará mais desafogada da especulação imobiliária, que levou centenas de famílias a deixarem suas casas alugadas para irem invadir terreno do Parque da Cidade, protegido ambientalmente, levando o município a sofrer Ação Civil Pública do Ministério Público Estadual para desocupação do Parque", explicou a procuradora do Trabalho Elaine Nassif.
\end{abstract}

As atividades desportivas previstas no TAC se destinam a criar opções para o tempo livre do trabalhador, beneficiando a cidade também neste aspecto, que receberá a construção de quadras de esporte e campeonato de futebol até outubro de 2014.

Conceição do Mato Dentro é onde é implantado parte do Projeto Minas-Rio. O projeto de mineração envolve ainda a cidade vizinha de Alvorada de Minas, que juntas devem produzir 26,5 milhões de toneladas de ferro por ano. $\mathrm{O}$ minério será transportado até o Porto de Açu $(\mathrm{RJ})$ para exportação através do maior mineroduto do mundo, o sistema Minas-Rio, com $525 \mathrm{~km}$ de extensão.

As condições degradantes de trabalho, a que eram constantemente submetidos os trabalhadores nas diversas atividades relacionadas à mineração na cidade de Conceição do Mato Dentro ${ }^{17}$, geraram um sentimento de revolta entre os trabalhadores. Nesse contexto, no dia 03 de julho de 2013, houve uma rebelião de operários contra as condições degradantes de trabalho, com o incêndio dos alojamentos e refeitórios da empresa mineradora, que materializavam as condições desumanas a que eram submetidos os trabalhadores, com alojamentos infestados por ratos e com alimentação azeda e imprópria para consumo.

A revolta dos trabalhadores foi divulgada por vídeo ${ }^{18}$ e pelo jornal "A Nova Democracia", em matéria jornalística intitulada "Operários estariam encarcerados e

\footnotetext{
${ }^{17}$ Nesse sentido, o jornal "O Tempo" publicou matéria jornalística intitulada Anglo American é autuada por trabalho análogo à escravidão, no dia no dia 24/04/2014, de autoria das jornalistas Ana Paula Pedrosa e Queila Ariadne, com o seguinte conteúdo: "Entre julho e outubro do ano passado (2013), um mecânico montador, contratado para as obras de implantação do projeto Minas-Rio, que inclui o maior mineroduto do mundo, ligando Conceição do Mato Dentro, região Central de Minas Gerais, ao Rio de Janeiro, trabalhou durante 88 dias seguidos, sem um dia sequer de descanso. Em $1^{\circ}$ de agosto de 2013, um motorista que trabalhava na mesma obra começou sua jornada às $6 \mathrm{~h}$ e só encerrou o expediente 20 horas depois, às $2 \mathrm{~h}$ do dia seguinte. Quatro horas depois, novamente às $6 \mathrm{~h}$, já estava no batente de novo. Jornadas exaustivas como essas, que colocam em risco a saúde e a segurança do trabalhador, levaram o Ministério do Trabalho e Emprego (MTE) a autuar a Anglo American, responsável pelo projeto Minas-Rio, e mais três empresas que prestavam serviços para ela de forma terceirizada - Milplan, Enesa e Construtora Modelo - por trabalho análogo à escravidão. As histórias relatadas acima foram contadas por algumas das 185 vítimas, que eram submetidas a jornadas de até 200 horas extras por mês durante até cinco meses. As investigações do MTE começaram em novembro do ano passado, a pedido da Comissão de Direitos Humanos da Assembleia Legislativa de Minas Gerais. Foram enquadrados em condições análogas às da escravidão os empregados que fizeram, no mínimo, 60 horas extras por mês durante pelo menos três meses". Disponível em: http://www.otempo.com.br/capa/economia/anglo-american-\%C3\%A9-autuada-por-trabalhoan\%C3\%A1logo-\%C3\%A0-escravid\%C3\%A3o-1.827736. Acesso em: 25/02/2018, às 12:30 horas. $18 \mathrm{O}$ vídeo do incêndio do alojamento e refeitório está disponível em: https://www.youtube.com/watch?v=yRdxEkUc9MQ. Acesso em 25/02/2018, às 13:30.
} 
incomunicáveis", publicada na $1^{\text {a }}$ quinzena de agosto de 2013, com o seguinte conteúdo informativo:

Em três de julho, cerca de 800 trabalhadores terceirizados da Montcalm, que prestam serviços para a Anglo American em Conceição do Mato Dentro, região central de Minas Gerais, deflagraram greve exigindo melhores salários, vale-alimentação, o pagamento de horas-extras e contra as péssimas condições de trabalho.

Durante a greve, galpões que serviam de alojamento foram incendiados e os trabalhadores foram brutalmente reprimidos.

A redação de AND foi informada dos acontecimentos por apoiadores do jornal residentes em Diamantina, cidade próxima a Conceição do Mato Dentro, e praticamente não há informações sobre a greve. Soubemos que, após a greve, forte aparato policial foi mantido nas imediações da empresa e patrulhando a cidade.

Matéria veiculada no jornal local noticiou que pelo menos dois operários foram presos, mas moradores da região e trabalhadores da Anglo American denunciam que pelo menos três trabalhadores presos durante a greve encontram-se encarcerados e incomunicáveis desde então.

Apuramos também graves denúncias de que além da exploração mineral e degradação das riquezas naturais, a mineradora tem expulsado os camponeses, impedido o trânsito de visitantes e moradores locais em estradas ${ }^{19}$.

Com base nos dados concretos acima indicados, pode-se afirmar que os benefícios proporcionados pela implantação do empreendimento minerário na cidade do Serro existem, apenas, no pensamento dos críticos da decisão do CODEMA. Pois, ao se analisar o próprio EIA/RIMA apresentado pela empresa mineradora e a realidade da implantação da mineração pela mesma empresa mineradora, no município vizinho de Conceição do Mato Dentro, com a submissão dos trabalhadores a condições análogas à escravidão, percebe-se que as crenças de um surto de desenvolvimento na cidade do Serro, com a implantação do empreendimento minerário, não encontram amparo na realidade.

A implantação do empreendimento minerário produziria um aumento de aproximadamente 200 vagas de empregos na cidade do Serro, durante aproximadamente 12 anos de funcionamento do empreendimento minerário, sendo que a maioria dos empregos disponíveis seriam mal remunerados e com sujeição dos trabalhadores a condições análogas à escravidão.

Assim, as externalidades positivas do empreendimento minerário denominado "Projeto Serro" são limitadíssimas. Por outro lado, quando se analisa as externalidades

19 A matéria jornalística está disponível em: http://anovademocracia.com.br/no-114/4846-operariosestariam-encarcerados-e-incomunicaveis. Acesso: 25/02/2018, às 13:30. 
negativas, constata-se que o empreendimento minerário causará prejuízos irreparáveis e de difícil compensação para toda a sociedade serrana, especialmente para os grupos étnicos subalternizados.

As externalidades negativas mais relevantes são a seguir enumeradas: 1) a necessidade de remoção da comunidade quilombola de Queimadas de seu território tradicional, na medida em que há uma sobreposição entre a área de influência direta do empreendimento minerário e o território ocupado pela comunidade quilombola para a reprodução de seu modo de vida; 2) a sobreposição do empreendimento minerário com a zona de amortecimento do Parque Estadual do Pico do Itambé, com reflexos negativos à preservação da biodiversidade da unidade de proteção integral; e, 3) a diminuição dos recursos hídricos disponíveis para a utilização humana, em virtude da sobreposição do empreendimento minerário com a área de recarga hídrica das bacias do Rio do Peixe e do Rio Guanhães.

Em relação à primeira externalidade negativa acima indicada, pode-se afirmar que a área de influência direta do empreendimento minerário se sobrepõe ao território da comunidade quilombola de Queimadas. E, a partir da análise das diferentes lógicas de utilização dos recursos naturais ostentadas pela forma de vida quilombola e pelo modo de produção de minério de ferro descrito no EIA/RIMA da empresa mineradora, percebese que as duas lógicas de uso dos recursos naturais não podem coexistir, devendo-se escolher uma ou outra forma de uso dos recursos naturais.

Pois, enquanto a empresa mineradora pretende instalar e operar estruturas de extração de minério de ferro (cava, pilha de estéreis, pilha de estoque, planta de britagem e classificação granulométrica, diques de contenção e estradas de interligação entre as diferente estruturas), com uso de mão-de-obra assalariada, a comunidade quilombola de Queimadas é um grupo étnico, que, ao realçar determinados traços culturais constitutivos de sua identidade, se afirma perante os demais grupos sociais em virtude de sua alteridade. A identidade étnica é o fator de coesão do grupo, cuja reprodução material é garantida pela exploração agropecuária, em regime de economia familiar, com a destinação da produção agrícola para a subsistência do grupo familiar e com comercialização do excedente produzido ${ }^{20}$. A comunidade quilombola de Queimadas é composta por,

\footnotetext{
${ }^{20}$ O processo de territorialização é descrito por Alfredo Wagner Berno de Almeida (2008, pp. 118/119) da seguinte maneira: "O processo de territorialização é resultante de uma conjunção de fatores, que envolvem a capacidade mobilizatória, em torno de uma política de identidade, e um certo jogo de forças em que os
} 
aproximadamente, 54 famílias e 245 pessoas, cuja reprodução material é assegurada pela exploração de atividade agropecuária, em regime de economia familiar, adotando uma forma de vida tipicamente camponesa.

O território quilombola deve ser entendido como o espaço necessário para a reprodução cultural, social e econômica de uma comunidade quilombola. O modo de ser de uma comunidade quilombola, que está materializado em sua organização social e em suas práticas culturais, sociais, religiosas, ancestrais e econômicas, foi construído e se mantém por meio da relação indissociável com mantém com o território ocupado pela comunidade, a partir do qual os conhecimentos, inovações e práticas foram gerados e transmitidos pela tradição.

A proteção jurídica do modo de ser de uma comunidade quilombola pressupõe, então, a garantia de que a comunidade poderá permanecer e utilizar os recursos naturais existentes em seu território, afastando-se qualquer outra lógica de uso e ocupação do território incompatível com a forma de vida quilombola.

Nesse sentido, o constitucionalista Daniel Sarmento (2010, pp. 281) explica o significado do território quilombola, nos seguintes termos:

Para comunidades tradicionais, a terra possui um significado completamente diferente da que ela apresenta para a cultura ocidental de massas. Não se trata apenas da moradia, que pode ser trocada pelo indivíduo sem maiores traumas, mas sim do elo que mantém a união do grupo, e que permite a sua continuidade no tempo através de sucessivas gerações, possibilitando a preservação da cultura, dos valores e do modo peculiar de vida da comunidade étnica.

Privado da terra, o grupo tende a se dispersar e a desaparecer, pois a identidade coletiva também periga sucumbir. Dessa forma, não é exagero afirmar que quando se retira a terra de uma comunidade quilombola, não se está apenas violando o direito à moradia dos seus membros. Muito mais que isso, se atenta contra a própria identidade étnica destas pessoas. Daí porque, o direito à terra dos remanescentes de quilombo é também um direito fundamental cultural (art. $215, \mathrm{CF})$.

Neste ponto, não é preciso enfatizar que o ser humano não é um ente abstrato e desenraizado, mas uma pessoa concreta, cuja identidade é também

agentes sociais, através de suas expressões organizadas, travam lutas e reivindicam direitos face ao Estado. As relações comunitárias neste processo também se encontram em transformação, descrevendo a passagem de uma unidade afetiva para uma unidade política de mobilização ou de uma existência atomizada para uma existência coletiva. A chamada "comunidade tradicional" se constitui nesta passagem. O significado de "tradicional" mostra-se, deste modo, dinâmico e como um fato do presente, rompendo com a visão essencialista e de fixidez de um território, explicado principalmente por fatores históricos ou pelo quadro natural, como se cada bioma correspondesse necessariamente uma certa identidade. A construção política de uma identidade coletiva, coadunada com a percepção dos agentes sociais de que é possível assegurar de maneira estável o acesso a recursos básicos, resulta, deste modo, numa territorialidade específica que é produto de reivindicações e de lutas. Tal territorialidade consiste numa forma de interlocução com antagonistas e com o poder do Estado". 
constituída por laços culturais, tradições e valores socialmente compartilhados. E nos grupos tradicionais, caracterizados por uma maior homogeneidade cultural e por uma ligação mais orgânica entre os seus membros, estes aspectos comunitários da identidade pessoal tendem a assumir uma importância ainda maior.

Por isso, a perda da identidade coletiva para os integrantes destes grupos costuma gerar crises profundas, intenso sofrimento e uma sensação de desamparo e de desorientação, que dificilmente encontram paralelo entre os integrantes da cultura capitalista de massa.

Assim, é possível traçar com facilidade uma ligação entre o princípio da dignidade da pessoa humana - epicentro axiológico da Constituição de 88 com o art. 68 do ADCT, que almeja preservar a identidade étnica e cultural dos remanescentes de quilombos. Isto porque, a garantia da terra para o quilombola é pressuposto necessário para a garantia de sua própria identidade.

A implantação do empreendimento minerário acarretaria, inevitavelmente, no etnocídio da comunidade quilombola de Queimadas. Ora, a promoção de crescimento econômico, por maior que seja (o que não é caso do "Projeto Serro", que é um empreendimento minerário experimental e de baixa capacidade produtiva), não justifica o extermínio de uma forma de vida humana; de uma das formas pelas quais a humanidade expressa a sua existência.

O respeito ao direito fundamental da comunidade quilombola de Queimadas ao uso e à propriedade coletiva de seu território justifica, por si só, a declaração de desconformidade socioambiental de um empreendimento econômico incompatível com a forma de vida quilombola.

Em relação à segunda externalidade negativa acima indicada, pode-se afirmar que a área de influência direta do empreendimento econômico se sobrepõe à zona de amortecimento do Parque Estadual do Pico do Itambé, com reflexos negativos à preservação da biodiversidade da unidade de proteção integral.

O Parque Estadual do Pico do Itambé (PEPI) foi criado pelo Decreto Legislativo $\mathrm{n}^{\circ} 39.398 / 98$, com o objetivo de proteger as riquezas naturais, formadas por cachoeiras, cursos d'água, flora e fauna únicas, em uma área de aproximadamente 4.700 ha (quatro mil e setecentos hectares), localizada nos municípios de Santo Antônio do Itambé, Serro e Serra Azul de Minas.

O PEPI fica situado na região alta do Vale do Jequitinhonha, estando inserido no complexo da Serra do Espinhaço. Abrange em seus domínios, várias nascentes e cabeceiras de rios das bacias do Jequitinhonha e Rio Doce, sendo conhecido na região como "caixa d' água". Possui ainda uma fauna e flora variada, além de recursos naturais 
de beleza cênica, como cachoeiras e formações rochosas. Destaca-se o Pico do Itambé, com seus 2.052 metros, um dos marcos referenciais do Estado e ponto culminante da Serra do Espinhaço.

O PEPI é uma Unidade de Conservação de Proteção Integral, que possui a finalidade de assegurar a preservação de ecossistemas naturais de grande relevância ecológica e beleza cênica.

Por isso, em Parques Estaduais, não é admitida a realização de atividades, de caráter econômico ou não, que acarretem a coleta e uso direto dos recursos naturais. Ao contrário, em Parques Estaduais, é admitida, apenas, a realização de "pesquisas científicas e o desenvolvimento de atividades de educação e interpretação ambiental, de recreação em contato com a natureza e de turismo ecológico" (art. 11 da Lei Federal n. ${ }^{\circ}$ 9.985/2000).

Além de restrições ao uso dos recursos naturais existentes no interior do PEPI, há, também, restrições ao uso dos recursos naturais existentes na zona de amortecimento, entendida como o "entorno de uma unidade de conservação, onde as atividades humanas estão sujeitas a normas e restrições específicas, com o propósito de minimizar os impactos negativos sobre a unidade" (art. 2. ${ }^{\circ}$, inciso XVIII, da Lei Federal n. ${ }^{\circ}$ 9.985/2000).

Pode-se afirmar, então, que a zona de amortecimento é o espaço geográfico que fica no entorno da unidade de conservação, no qual há restrições na exploração dos recursos naturais, com vistas a reduzir os impactos provocados na unidade de conservação pelas pressões do entorno.

A Zona de Amortecimento do PEPI é descrita no item 4.4.8 do Plano de Manejo desta Unidade de Conservação de Proteção Integral, nos seguintes termos:

Os limites estabelecidos para a zona de amortecimento foram definidos com base nos critérios técnicos dos profissionais envolvidos no trabalho e de acordo com os objetivos de manejo, no sentido de possibilitar a proteção dos recursos naturais e o fluxo gênico das populações florísticas e faunísticas do Parque. Os limites estabelecidos para a zona de amortecimento foram:

- Limite Norte: divisa dos municípios de Couto de Magalhães de Minas com Serro, estendendo-se pela margem direita do córrego Soberbo;

- Limite Sul: divisa dos municípios de Santo Antônio do Itambé com Serro, seguindo-se pelo córrego Salomé, córrego Bom Sucesso e afluente do rio Jequitinhonha até o limite com o próprio rio Jequitinhonha;

- Limite oeste: do Sul para o Norte, abrange parte do rio Jequitinhonha, cruzando o córrego Condadinho e o córrego do Rico, seguindo pelo córrego Mara, cruzando pelo ribeirão da Lomba (Ribeirão Soberbo) até atingir o limite dos municípios de Couto de Magalhães de Minas com Serro; e, 
- Limite leste: de Norte para o Sul, abrange escarpa a Leste, desce pelo córrego Teodósio, cruza o rio Vermelho, desce abrangendo as nascentes do ribeirão Cipó, cruza o córrego Água Santa, o rio Guanhães, o ribeirão da Areia e o córrego São João, abrangendo as nascentes desses rios, até atingir o córrego Luzia, na linha de divisa dos municípios de Couto de Magalhães de Minas com Serro.

O Plano de Manejo do PEPI estabelece a norma específica que "as atividades a serem implantadas na Z.A. não poderão conflitar com os objetivos específicos de manejo do Parque, nem comprometer a integridade do seu patrimônio" (p. 4.21). E, no item 4.6.2.2.2, descreve, pormenorizadamente, as atividades que poderão ser desenvolvidas na zona de amortecimento do PEPI, nos seguintes termos:

1. Incentivar práticas ambientais sustentáveis no entorno;

2. Envolver a comunidade como aliada na preservação do Parque: formação de condutores locais, utilização de mão-de-obra local nos serviços;

3. Difundir junto às comunidades do entorno sistemas agrícolas / florestais adequados às condições ambientais e socioeconômicas da região;

4. Fomentar o ecoturismo de observação de aves no Parque e entorno;

4.1. Efetuar inventário das aves do Parque e entorno, e identificar locais propícios para a observação turística de aves e espécies de maior interesse passíveis de serem observadas;

4.2. Capacitação de pessoas para atuarem como condutores e identificadores de aves;

5. Fomentar a meliponicultura com espécies indígenas:

5.1. Diagnosticar as espécies de abelhas indígenas da região com potencial de uso para a meliponicultura;

5.2. Estruturar projeto de implantação da meliponicultura no entorno do Parque, incluindo pesquisa de mercado;

\subsection{Fomentar a implantação do projeto de meliponicultura.}

Norma: As atividades deverão ser desenvolvidas com auxílio de especialistas; e,

Norma: Não poderão ser introduzidas espécies de abelhas exóticas ou oriundas de biomas diferentes da existente.

6. Fomentar a agricultura e fruticultura orgânica no entorno; e,

7. Apoiar a implementação de projetos regionais em Desenvolvimento.

Em face da descrição das atividades humanas permitidas na Área de Amortecimento do PEPI, tais como agricultura e fruticultura orgânica, meliponicultura 
com espécies indígenas, ecoturismo de observação de aves, dentre outras, constata-se que se trata de atividades de baixo impacto ambiental, que se caracterizam por não perturbar o ciclo natural do ecossistema existente.

Nesse sentido, as atividades de baixo impacto ambiental são aquelas que não comprometem as funções ambientais naturais, propiciando a preservação da estabilidade das encostas e margens dos corpos de água, os corredores de fauna, a drenagem e os cursos de água intermitentes, a manutenção da biota, a regeneração e a manutenção da vegetação nativa e a quantidade e qualidade das águas.

O Novo Código Florestal, instituído pela Lei Federal n. ${ }^{\circ}$ 12.651/12, estabeleceu diretrizes normativas para a identificação e caracterização das atividades a serem consideradas de baixo impacto ambiental. Assim, o artigo $3^{\circ}$, inciso X, do Novo Código Florestal estatui que:

Art. 3ํ Para os efeitos desta Lei, entende-se por:

$[\ldots]$

$\mathrm{X}$ - atividades eventuais ou de baixo impacto ambiental:

a) abertura de pequenas vias de acesso interno e suas pontes e pontilhões, quando necessárias à travessia de um curso d'água, ao acesso de pessoas e animais para a obtenção de água ou à retirada de produtos oriundos das atividades de manejo agroflorestal sustentável;

b) implantação de instalações necessárias à captação e condução de água e efluentes tratados, desde que comprovada a outorga do direito de uso da água, quando couber;

c) implantação de trilhas para o desenvolvimento do ecoturismo;

d) construção de rampa de lançamento de barcos e pequeno ancoradouro;

e) construção de moradia de agricultores familiares, remanescentes de comunidades quilombolas e outras populações extrativistas e tradicionais em áreas rurais, onde o abastecimento de água se dê pelo esforço próprio dos moradores;

f) construção e manutenção de cercas na propriedade;

g) pesquisa científica relativa a recursos ambientais, respeitados outros requisitos previstos na legislação aplicável;

h) coleta de produtos não madeireiros para fins de subsistência e produção de mudas, como sementes, castanhas e frutos, respeitada a legislação específica de acesso a recursos genéticos;

i) plantio de espécies nativas produtoras de frutos, sementes, castanhas e outros produtos vegetais, desde que não implique supressão da vegetação existente nem prejudique a função ambiental da área; 
j) exploração agroflorestal e manejo florestal sustentável, comunitário e familiar, incluindo a extração de produtos florestais não madeireiros, desde que não descaracterizem a cobertura vegetal nativa existente nem prejudiquem a função ambiental da área;

k) outras ações ou atividades similares, reconhecidas como eventuais e de baixo impacto ambiental em ato do Conselho Nacional do Meio Ambiente CONAMA ou dos Conselhos Estaduais de Meio Ambiente;

Ora, a atividade minerária deve ser considerada como altamente poluidora, na medida em que promove a degradação da qualidade ambiental por afetar desfavoravelmente a biota e as condições estéticas e sanitárias do meio ambiente. Assim, não é possível considerar o Projeto Serro como atividade de baixo impacto ambiental e, consequentemente, não é possível declarar a conformidade do uso da Zona de Amortecimento do PEPI para a implantação de empreendimento minerário, na medida em que a atividade minerária na zona de amortecimento irá impactar, de modo negativo, a preservação da flora e fauna existente no PEPI.

Por fim, em relação à terceira externalidade negativa acima indicada, pode-se afirmar que a área de influência direta do empreendimento minerário se sobrepõe à área de recarga hídrica das bacias do Rio do Peixe e do Rio Guanhães, com a diminuição dos recursos hídricos disponíveis para a utilização humana.

A bacia hidrográfica do Rio do Peixe é utilizada para a captação dos recursos hídricos que abastecem a cidade do Serro. Ademais, inúmeras comunidades rurais, tais como Queimadas, Mata da Saia, Córrego da Prata, Ponte de Pedra, Lucas, Peixoto, dentre outras, são abastecidas com os recursos hídricos provenientes do Córrego Siqueira.

Assim, a implantação do empreendimento minerário coloca em risco o abastecimento hídrico de todas as pessoas que moram na cidade do Serro, bem como daqueles que vivem nas comunidades rurais acima indicadas.

Os impactos nas bacias do Rio do Peixe e do Rio Guanhães, que seriam causados pela implantação do empreendimento minerário, são descritos no Estado de Impacto Ambiental e Relatório de Impacto ao Meio Ambiente (EIA/RIMA, 2014, volume 3, p. 22), nos seguintes termos:

Na fase de implantação do Projeto Serro, que compreenderá os trabalhos iniciais de desenvolvimento das cavas, pilha de estoque, pilha de estéril, além das obras de todas as instalações e sistemas de apoio necessários, serão desenvolvidas atividades que tenderão a expor em maior grau a superfície dos solos às ações das chuvas, tais como: supressão da vegetação, terraplenagem, movimentação dos solos para instalação do canteiro de obras e de 
infraestruturas de apoio, abertura e melhorias de estradas e de acessos e implantação dos sistemas de controle, como os diques de contenção. A geração e carreamento de sedimentos em decorrência destas atividades poderão provocar assoreamento da rede de drenagem, ou seja, acúmulo de detritos e substâncias minerais ou orgânicas nos corpos d'água, provocando a redução de sua profundidade e velocidade de fluxo.

Conforme mencionado ao longo do diagnóstico ambiental, as estruturas do empreendimento onde serão concentradas as obras de implantação do projeto estão localizadas na sub-bacia do córrego Siqueira, embora também faça parte da AID do empreendimento um trecho da sub-bacia do rio do Peixe.

Como os rios que drenam as áreas de influência do Projeto Serro em geral apresentam pequeno porte, haverá impacto significativo nos corpos d'água decorrentes do carreamento de sólidos caso não sejam adotadas medidas mitigadoras adequadas durante as obras. As atividades supracitadas, portanto, poderão desencadear ou intensificar os processos erosivos dos solos e o transporte de materiais diversos e de sedimentos aos corpos d'água adjacentes, especialmente no período chuvoso, provocando o assoreamento e, consequentemente, diminuição das seções naturais das drenagens.

O fluxo de sólidos promove ainda interferências na qualidade das águas superficiais, com aumento dos níveis de cor, sólidos e de turbidez, podendo também acarretar maior concentração de metais, como ferro e manganês, elementos típicos da matriz geológica regional. Esses componentes interferem nas condições estéticas das águas e na produtividade biológica do sistema aquático, impacto esse potencializado no período de chuvas.

Vale ressaltar que o diagnóstico das águas superficiais da região apontou que as mesmas atualmente apresentam, em geral, boa qualidade, com baixos teores de sólidos, turbidez e cor verdadeira na maior parte dos pontos amostrados da AID. (grifos nossos).

Os impactos aos recursos hídricos da região são dimensionados como negativos, prováveis, dispersos, permanentes e irreversíveis. Senão vejamos:

Embora a Caracterização do Empreendimento não deixe clara a necessidade de rebaixamento do lençol freático, pelas características apresentadas pelos poços presentes na região, é possível que o nível do lençol freático seja alcançado durante as atividades de extração de minério.

Dentro dos limites da AID foram constatados os sistemas aquíferos porosos, cristalinos e o aquitardo; porém as intervenções diretas, que ocorrerão na ADA, estarão sobre os aquiíferos porosos e fraturados. Nos aquíferos porosos, há grande volume de água e esta escoa em qualquer direção, de acordo com os diferenciais hidrostáticos da área. Nos aqüíferos fraturados, as águas se concentram nas fraturas e tendem a ter orientação preferencial.

O rebaixamento do lençol freático, se confirmado pelo empreendimento, deverá ocorrer de forma localizada, na área da cava; porém poderá afetar tanto as nascentes do córrego Siqueira quanto as nascentes do rio do Peixe. Conforme informado no diagnóstico, a captação de água para abastecimento do município de Serro é realizada no rio do Peixe. Como poucas nascentes do rio do Peixe apresentam potencial para serem atingidas, acredita-se que não 
haverá comprometimento do abastecimento a jusante. Ressalta-se que caso seja realmente necessário o rebaixamento do lençol freático, o empreendedor deverá solicitar outorga junto ao órgão ambiental competente e realizar estudos hidrogeológicos mais detalhados para a área de tal forma a se confirmar o grau de interferência dessa operação no nível freático da área e, consequentemente, na disponibilidade hídrica ofertada pelo ambiente.

Trata-se de um impacto negativo, provável, disperso, pois embora o rebaixamento do lençol freático aconteça na área da cava, os fluxos de água subterrânea da AID também seriam atingidos; de ocorrência em médio prazo; permanente; irreversível; fato novo; de média magnitude." (grifos nossos) (EIA/RIMA, 2014, volume 3, p. 90).

Com base no EIA/RIMA apresentado pela própria empresa mineradora, pode-se afirmar que a implantação do empreendimento minerário ocasionará o risco de diminuição dos recursos hídricos da região, especificamente da bacia hidrográfica utilizada para o abastecimento hídrico de cerca de 15.000 pessoas (população que reside na área urbana do município do Serro).

Essa conclusão é reforçada pelo próprio EIA/RIMA, que, ao realizar uma comparação entre o cenário atual (sem o empreendimento) e o cenário futuro (com o empreendimento e as medidas mitigatórias a serem adotadas), sustenta que:

Sem o empreendimento: Espera-se a manutenção do nível do lençol freático e vazão atual dos cursos d'água superficiais, bem como da qualidade das águas.

Com o empreendimento: $O$ provável rebaixamento do nível d'água subterrâneo poderá afetar tanto nascentes do córrego Siqueira quanto nascentes do rio do Peixe. (grifos nossos). (EIA/RIMA, 2014, volume 3, p. 90).

Percebe-se, então, que a implantação do empreendimento minerário produzirá impactos negativos no Rio do Peixe e no Córrego do Siqueira, em virtude da provável diminuição da disponibilidade hídrica ocasionada pela extinção de nascentes existentes no local. Além de compor a paisagem da região, esses cursos d'água são utilizados para o abastecimento humano, dessedentação de animais, lazer e outros usos sociais.

Constata-se, assim, a existência de um conflito estrutural e de difícil solução, na medida em que diferentes grupos sociais pretendem utilizar o mesmo território de modo diferente e contraditório. Pois, enquanto a população serrana utiliza a AID do empreendimento minerário como fonte de captação de recursos hídricos destinados à satisfação das zonas urbana e rural, o empreendedor pretende utilizar a mesma área para 
a produção de mercadoria (minério de ferro) a ser comercializada no mercado internacional.

O conflito emerge, justamente, porque estas duas formas de uso do território não podem coexistir ao mesmo tempo. Pois, enquanto a população possui o interesse em preservar os recursos hídricos disponíveis no território, bem como os recursos de fauna e flora e os espaços constituidores da identidade étnica de diferentes grupos sociais, a mineradora se interessa pelo valor econômico do minério existente no substrato geológico, almejando a reprodução do capital.

Contudo, é impossível promover a exploração minerária sem provocar impactos negativos aos recursos naturais da superfície, ou desestruturar os espaços simbólicos e a paisagem, inviabilizando, assim, a continuidade do uso daquele espaço pela população serrana.

Nesse sentido, Henri Acserald (2004, p. 26) explica os conflitos ambientais nos seguintes termos:

\begin{abstract}
Os conflitos ambientais são, portanto, aqueles envolvendo grupos sociais com modos diferenciados de apropriação, uso e significação do território, tendo origem quando pelo menos um dos grupos tem a continuidade das formas sociais de apropriação do meio que se desenvolvem ameaçada por impactos indesejáveis - transmitidos pelo solo, água, ar ou sistemas vivos - decorrentes do exercício das práticas de outros grupos. O conflito pode derivar da disputa por apropriação de uma mesma base de recursos ou de bases distintas, mas interconectadas por interações ecossistêmicas mediadas pela atmosfera, pelo solo, pelas águas etc. Este conflito tem por arena unidades territoriais compartilhadas por um conjunto de atividades cujo "acordo simbiótico" é rompido em função da denúncia dos efeitos indesejáveis da atividade de um dos agentes sobre as condições materiais do exercício das práticas de outros agentes.
\end{abstract}

O empreendimento minerário denominado "Projeto Serro" foi pensado, exclusivamente, para aumentar, na maior medida do possível, a reprodução do capital pela exploração minerária, em detrimento e desconsideração do interesse público de preservação dos recursos hídricos existentes no território do município do Serro.

A eventual aprovação do empreendimento minerário denominado "Projeto Serro", com as características por ele apresentadas, representa a materialização de profunda injustiça socioambiental. Pois, ao mesmo tempo em que autoriza a privatização do uso e controle dos recursos naturais existentes por uma única empresa, exclui a totalidade dos serranos do direito de ter acesso aos recursos hídricos, que são imprescindíveis para a manutenção da vida e do bem-estar de toda a população serrana. 
Em outras palavras, a injustiça socioambiental consiste em permitir a privatização dos ganhos econômicos pelo empreendimento minerário, ao mesmo tempo em que as externalidades negativas do empreendimento minerário, especialmente a diminuição dos recursos hídricos disponíveis, a destruição da beleza paisagística da área e a redução da fauna aquática disponível, serão suportadas exclusivamente pela população serrana, em especial pelos mais pobres.

É oportuno esclarecer que, em nenhum momento, a empresa mineradora prevê a adoção de medidas mitigadoras eficientes para a preservação dos recursos hídricos existentes no local, de modo a assegurar o acesso da população aos recursos hídricos e à manutenção da população de peixes endêmicos existentes no Rio do Peixe. Ao contrário, o EIA/RIMA apresentado pela empresa mineradora prevê que as medidas mitigadoras previstas "apresentam baixo grau de resolução" (EIA/RIMA, 2014, volume 3, p. 91).

Na reunião extraordinária do CODEMA, realizada no dia 28 de outubro de 2015, com o objetivo exclusivo de deliberar sobre a declaração de (des)conformidade socioambiental do empreendimento minerário denominado "Projeto Serro", a questão hídrica uniu todas as classes e grupos étnicos constituintes da sociedade serrana, contra a autorização de implantação do empreendimento minerário.

Em outras palavras, a preservação dos recursos hídricos unificou, de modo temporário e precário, os interesses de todas as classes sociais e grupos étnicos constituidores da sociedade serrana, que, para viver bem, necessitam da preservação dos recursos hídricos existentes na região. Por isso, o CODEMA deliberou, de forma unânime, pela declaração de desconformidade socioambiental do empreendimento minerário denominado "Projeto Serro". Votaram contra a autorização de implantação do empreendimento minerário as seguintes instituições: Secretaria do Meio Ambiente do Município do Serro, Câmara de Vereadores do Município do Serro, Instituto Estadual de Florestas (IEF), Polícia Militar Ambiental de Minas Gerais, Pontifícia Universidade Católica de Minas Gerais (PUC-Minas), Associação Comercial do Serro e Sindicato dos Trabalhadores Rurais de Serro.

Ora, ao se ponderar as externalidades positivas e negativas proporcionadas pelo empreendimento minerário denominado "Projeto Serro, é fácil concluir que o empreendimento minerário atende, apenas, os interesses da empresa mineradora, sendo prejudicial a todas as pessoas que vivem na cidade do Serro. 
As críticas de conteúdo são falsas e distorcem as razões que levaram o CODEMA a deliberar pela declaração de desconformidade socioambiental do empreendimento minerário denominado "Projeto Serro".

Pois, o CODEMA não desconsiderou os benefícios que seriam proporcionados pela implantação do empreendimento minerário. Os benefícios foram, na verdade, considerados limitadíssimos, na medida em que se restringiam a criação de 200 empregos, mal remunerados e com submissão dos trabalhadores a condições degradantes e análoga à condição de escravos.

Nem se tente argumentar, como fazem os críticos da decisão do CODEMA, de que “[...] não necessariamente, (sic) a experiência da cidade de Conceição do Mato Dentro/MG tem que se repetir na cidade do Serro/MG”. Trata-se, mais uma vez, de uma demonstração de fé, desprovida de qualquer racionalidade e de qualquer relação com a realidade, que distorce a realidade no intuito de ocultar as relações de opressão e exploração advindas da implantação do empreendimento minerário.

Pois, se a realidade existente na cidade de Conceição do Mato Dentro após a implantação do empreendimento minerário é a síntese de múltiplas determinações, com preponderância para a postura colonialista da empresa mineradora "Anglo American Minério de Ferro Brasil S.A." e para a postura submissa e subserviente aos interesses do capital dos órgãos estatais (especialmente, da Superintendência de Regularização Ambiental da Região do Jequitinhonha - SUPRAM/JEQ), a atuação da mesma empresa mineradora e do mesmo órgão estatal de controle ambiental na cidade do Serro promoverão, provavelmente, a mesma realidade de opressão e exploração das classes e grupos étnicos subalternizados.

Não há qualquer elemento objetivo que justifique a crença de que a implantação do empreendimento minerário na cidade do Serro irá produzir uma realidade diferente daquela vivenciada no município de Conceição do Mato Dentro, em relação à permissividade com a degradação ambiental, à inexigibilidade das condicionantes ambientais não atendidas pela empresa mineradora e às condições degradantes e análogas à escravidão a que são submetidos os trabalhadores envolvidos nas diversas atividades da mineração. 


\section{CONCLUSÃO}

A deliberação do CODEMA, que declarou a desconformidade socioambiental do empreendimento minerário denominado "Projeto Serro", resulta de uma ampla mobilização social, inclusive das classes e grupos étnicos historicamente subalternizados, na construção democrática de uma decisão estatal apropriada para a promoção e o respeito dos interesses materiais e valores das classes e grupos constituidores da sociedade serrana.

O procedimento de discussão e deliberação, em todas as suas etapas promovidas pelo CODEMA, orientou-se para assegurar a igual participação de todos os cidadãos serranos na construção da decisão coletivamente obrigatória, com especial atenção à participação das classes e grupos étnicos subalternizados ao longo do processo histórico de organização de uma ordem social baseada na hierarquização das pessoas a partir do critério da raça e da classe social.

Assim, do ponto de vista procedimental, promoveu-se inúmeras reuniões, audiências e seminários, com a mais ampla participação popular, com o propósito de compreender as externalidades positivas e negativas decorrentes da implantação do empreendimento minerário e, assim, deliberar sobre a compatibilidade do empreendimento minerário com os interesses das diversas classes e grupos étnicos constituidores da sociedade serrana. E, em especial atenção aos grupos étnicos subalternizados, o CODEMA exigiu a realização de consulta livre, prévia e informada aos órgãos representativos da comunidade Quilombola de Queimadas, com o intuito de neutralizar, na maior medida do possível, os efeitos das relações de colonialidade existentes na sociedade serrana.

A empresa mineradora adotou a postura de não participar das discussões públicas sobre o empreendimento minerário, atuando, ainda, para esvaziar os fóruns de discussão promovidos pelo CODEMA. Ademais, a empresa mineradora não aceitou, também, promover e participar dos processos de consulta livre, prévia e informada dos órgãos representativos da comunidade quilombola de Queimadas.

Por outro lado, do ponto de vista do conteúdo da decisão administrativa, o CODEMA se esforçou por levar, em igual consideração, os interesses de todas as classes e grupos étnicos constituidores da sociedade serrana, de modo a que sua decisão pudesse ser a expressão genuína e verdadeira de todos, ainda que numa sociedade colonial e 
classista. E, ao identificar, de modo temporário e precário, que o interesse de todas as classes e grupos étnicos confluíam para a preservação dos recursos hídricos existentes na região, o CODEMA deliberou, de forma unânime, pela declaração de desconformidade socioambiental do empreendimento minerário denominado "Projeto Serro", em respeito aos interesses dos cidadãos do Serro e em detrimento da pretensão de pura acumulação do capital.

As críticas formuladas contra a decisão do CODEMA são, na verdade, uma mistificação do que foi o processo de discussão e deliberação sobre a implantação do empreendimento minerário na cidade do Serro.

As críticas ocultam que a declaração de desconformidade socioambiental do empreendimento minerário foi tomada, de modo unânime, pelos representantes da Secretaria do Meio Ambiente do Município do Serro, da Câmara de Vereadores do Município do Serro, do Instituto Estadual de Florestas (IEF), da Polícia Militar Ambiental de Minas Gerais, da Pontifícia Universidade Católica de Minas Gerais (PUC-Minas), da Associação Comercial do Serro e do Sindicato dos Trabalhadores Rurais de Serro, para a preservação dos recursos hídricos existentes na região.

A população do Serro deve se orgulhar do processo de discussão e deliberação promovido pelo CODEMA, que, ao invés de se sujeitar aos interesses de expansão do capital, votou pelo bem-estar de todos os cidadãos serranos, garantindo a preservação dos recursos naturais da região, especialmente a garantia do acesso à água para todos os habitantes do município do Serro.

Por isso, o projeto de extensão "A luta pelo reconhecimento dos direitos fundamentais das comunidades remanescentes de quilombo" espera que o município do Serro respeite a declaração de desconformidade socioambiental do empreendimento minerário denominado "Projeto Serro", resguardando os interesses dos grupos subalternizados e não cedendo à imposição colonialista dos interesses de acumulação do capital.

\section{REFERÊNCIAS BIBLIOGRÁFICAS}

ACSELRAD, Henri (Org.). Conflitos Ambientais no Brasil. Rio de Janeiro: Relume Dumará, 2004, p. 26. 
ALMEIDA, Alfredo Wagner Berno de. Terras tradicionalmente ocupadas - processos de territorialização e movimentos sociais. Revista Brasileira de Estudos Urbanos e Regionais, vol. 6, n. ${ }^{\circ}$ 1, 2004, pp. 9-32.

ARCADIS LOGOS S.A. Estudo de Impacto Ambiental/Relatório de Impacto Ambiental. Belo Horizonte, Minas Gerais, Novembro de 2014. 4 volumes.

BRASIL. Decreto-lei n. ${ }^{\circ}$ 25, de 30 de novembro de 1937. Organiza a proteção do patrimônio histórico e artístico nacional. Diário Oficial da União. Rio de Janeiro, 30 de novembro de 1937. Disponível em: http://www.planalto.gov.br/ccivil_03/decretolei/Del0025.htm.

BRASIL. Constituição (1988). Constituição da República Federativa do Brasil. Brasília: Senado, 1988.

BRASIL. Lei n. ${ }^{\circ} 9.985$, de 18 de julho de 2000. Regulamento do art. $225, \S 1^{\circ}$, incisos I, II, III e VII da Constituição Federal, institui o Sistema Nacional de Unidades de Conservação da Natureza e dá outras providências. Diário Oficial da União. Brasília, 18 de julho de 2000. Disponível em:

http://www.planalto.gov.br/ccivil_03/leis/19985.htm.

BRASIL. Decreto n. ${ }^{\circ}$ 5.051, de 19 de abril de 2004. Promulga a Convenção n. ${ }^{\circ} 169$ da Organização Internacional do Trabalho - OIT sobre Povos Indígenas e Tribais. Diário Oficial da União, Brasília, 19 de abril de 2004. Disponível em: http://www.planalto.gov.br/ccivil_03/_ato2004-2006/2004/decreto/d5051.htm.

BRASIL. Decreto n. ${ }^{\circ}$ 6.040, de 07 de fevereiro de 2007. Institui a Política Nacional de Desenvolvimento Sustentável dos Povos e Comunidades Tradicionais. Diário Oficial da União. Brasília, 7 de fev. 2007. Disponível em: http://www.planalto.gov.br/ccivil_03/_ato2007-2010/2007/decreto/d6040.htm.

CHAUÍ, Marilena. O que é ideologia? São Paulo: Editora Brasilense, 2008.

CONSELHO NACIONAL DO MEIO AMBIENTE - CONAMA. Resolução n. ${ }^{\circ}$ 237, de 19 de dezembro de 1997. Regulamenta os aspectos de licenciamento ambiental estabelecidos na Política Nacional do Meio Ambiente. Diário Oficial da União, n. ${ }^{\circ}$ 247, de 22/12/1997, págs. 30.841-30.843.

DUPRAT, Deborah. A convenção 169 da OIT e o direito à consulta prévia, libre e informada. Revista Culturas Jurídicas, n. ${ }^{\circ}$ 1, vol. 1, 2014.

JUSTEN FILHO, Marçal. Curso de Direito Administrativo. São Paulo: Editora Saraiva, 2009.

LITTLE, Paul Elliot. Territórios sociais e povos tradicionais no Brasil: por uma antropologia da territorialidade. Anuário Antropológico 2002/2003. Rio de Janeiro: Tempo Brasileiro, 2004.

LYRA FILHO, Roberto. O que é o Direito? São Paulo: Brasiliense, 1999. 
MARX, Karl. Grundrisse: manuscritos econômicos de 1857-1858: esboços da crítica da economia política. São Paulo: Boitempo; Rio de Janeiro: Ed. UFRJ, 2011.

MARX, Karl; ENGELS, Friedrich. Manifesto Comunista. São Paulo: Editora Boitempo, 2017.

MILARÉ, Édis. Direito do Ambiente: doutrina, jurisprudência, glossário. São Paulo: Editora Revista dos Tribunais, 2004.

NETTO, José Paulo. Introdução ao Estudo do Método de Marx. São Paulo: Expressão Popular, 2011.

QUIJANO, Aníbal. Cuestiones y horizontes: de la dependência histórico-estructural a la colonialidad/descolonialidad del poder. Ciudad Autónoma de Buenos Aires: CLACSO, 2014.

SARMENTO, Daniel. Por um constitucionalismo inclusivo: história constitucional brasileira, teoria da constituição e direitos fundamentais. Rio de Janeiro: Lumen Juris, 2010.

SERRO. Lei Municipal n. ${ }^{\circ}$ 1.815, de 27 de dezembro de 2005. Dispõe sobre a política municipal do meio ambiente, seus fins e mecanismos de formulação e aplicação. Serro, 2005.

SERRO. Lei Municipal n. ${ }^{\circ}$ 1.816, de 27 de dezembro de 2005. Dispõe sobre o Conselho de Desenvolvimento do Meio Ambiente. Serro, 2005.

SERRO. Conselho Municipal de Desenvolvimento do Meio Ambiente - CODEMA. Deliberação n. ${ }^{\circ}$ 001/2015, de 28 de outubro de 2015. Dispõe sobre a solicitação de Declaração de Conformidade Ambiental. Prefeitura Municipal do Serro.

SERRO. Prefeitura Municipal. Termo de Homologação. Dispõe sobre a homologação da deliberação 01, de 28 de outubro de 2015 do Conselho Municipal de Desenvolvimento do Meio Ambiente - CODEMA, para fins de declarar a não conformidade do Projeto Serro - Planta Azteca da Empresa Anglo American. Afixado no Quadro de Publicações da Prefeitura Municipal do Serro no período de 20/11/2015 a 20/12/2015.

SERRO. Lei Municipal n. ${ }^{\circ}$ 3.074, de 25 de maio de 2017. Altera o art. $4^{\circ}$ da Lei . $^{\circ}$ 1.816, de 27 de dezembro de 2005, com redação dada pela Lei n. ${ }^{\circ} 2827$, de 16 de outubro de 2014, que cria o Conselho Municipal de Meio Ambiente e dá outras providências. Prefeitura Municipal do Serro. Disponível em: https://leismunicipais.com.br/a1/mg/s/serro/lei-ordinaria/2017/308/3074/lei-ordinaria-n3074-2017-altera-o-art-4-da-lei-n-1816-de-27-de-dezembro-de-2005-com-redacaodada-pela-lei-n-2827-de-16-de-outubro-de-2014-que-cria-o-conselho-municipal-demeio-ambiente-e-da-outras-providencias? $\mathrm{q}=3074$. 
Quaestio Iuris

Trabalho recebido em 07 de dezembro de 2019

Aceito em 01 de outubro de 2020 